\title{
Fluidics System for Resolving Concentration-Dependent Effects of Dissolved Gases on Tissue Metabolism
}

\section{Varun Kamat ${ }^{1}$, Brian M. Robbings ${ }^{1,3}$, Seung-Ryoung Jung ${ }^{1}$, John Kelly², James B. Hurley ${ }^{3}$, Kenneth P. Bube ${ }^{4}$ and Ian R. Sweet ${ }^{1}$}

\section{From}

${ }^{1}$ University of Washington Medicine Diabetes Institute, University of Washington, Seattle, WA, 98109.

${ }^{2}$ VICI Metronics, 26295 Twelve Trees, Poulsbo, Washington 98370

${ }^{3}$ Department of Biochemistry, University of Washington, Seattle, WA, 98109

${ }^{4}$ Department of Mathematics, University of Washington, Seattle, WA, 98195

Running Title: Dissolved Gases and Electron Transport.

Address correspondence to: Ian R Sweet, Box \# 358062, F763, UW Medicine Diabetes Institute, University of Washington, 750 Republican St Building F, Seattle, WA 98109-4725

Tel. (206) 685-4775; Fax: (206) 543-3169; E-mail: isweet@uw.edu

Varun Kamat and Brian Robbings are co-first authors. 
Dissolved Gases and Electron Transport

\begin{abstract}
Oxygen $\left(\mathrm{O}_{2}\right)$ and other dissolved gases such as the gasotransmitters $\mathrm{H}_{2} \mathrm{~S}, \mathrm{CO}$ and $\mathrm{NO}$ affect cell metabolism and function. To evaluate effects of dissolved gases on processes in tissue, we developed a fluidics system that controls dissolved gases while simultaneously measuring parameters of electron transport, metabolism and secretory function. We use pancreatic islets, retina and liver to highlight its ability to assess effects of $\mathrm{O}_{2}$ and $\mathrm{H}_{2} \mathrm{~S}$. Protocols aimed at emulating hypoxia-reperfusion conditions resolved a previously unrecognized transient spike in $\mathrm{O}_{2}$ consumption rate (OCR) following replenishment of $\mathrm{O}_{2}$, and tissue-specific recovery of OCR following hypoxia. The system revealed both inhibitory and stimulatory effects of $\mathrm{H}_{2} \mathrm{~S}$ on insulin secretion rate from isolated islets. The unique ability of this new system to quantify metabolic state and cell function in response to precise changes in dissolved gases provides a powerful platform for cell physiologists to study a wide range of disease states.
\end{abstract}

\author{
ABBRIEVIATIONS \\ $\mathrm{CO}_{2}$ - carbon dioxide \\ $\mathrm{CO}$ - carbon monoxide \\ ETC - electron transport chain \\ $\mathrm{H}_{2} \mathrm{~S}$ - hydrogen sulfide \\ ISR - insulin secretion rate \\ $\mathrm{KCN}$ - potassium cyanide \\ $\mathrm{LDH}$ - lactate dehydrogenase \\ MPC - mitochondrial pyruvate carrier \\ NaHS - sodium hydrosulfide \\ $\mathrm{NO}$ - nitric oxide \\ $\mathrm{O}_{2}$ - oxygen \\ OCR - oxygen consumption rate
}




\section{INTRODUCTION}

A critical need for instrumentation to study the effect of dissolved gases. Oxygen $\left(\mathrm{O}_{2}\right)$ is a fundamental determinant of cell survival and function in mammalian tissues. In most cells the majority of ATP is generated by oxidative phosphorylation, driven by a series of redox reactions in which $\mathrm{O}_{2}$ is the ultimate electron acceptor. Hypoxia is linked to many diseases including stroke, cancer, COVID-19 and diabetic complications. In addition to $\mathrm{O}_{2}$, trace gases produced by cells $\left(\mathrm{H}_{2} \mathrm{~S}, \mathrm{NO}\right.$ and $\left.\mathrm{CO}\right)$ act as signals to regulate cellular and mitochondrial function ${ }^{1}$. Ischemia-reperfusion injury is a condition common to many disease states and it is thought that during reoxygenation a burst of reactive $\mathrm{O}_{2}$ species (ROS) occurs that can damage proteins, lipids and nucleic acids ${ }^{2,3}$. Yet despite the scientific and clinical importance of dissolved gases, quantitative methods to measure the real time effects of dissolved gases on intact tissue are not available. Investigators who have studied trace gases and who are characterizing drugs to attain the same benefits ${ }^{4}$ almost exclusively use aqueous based surrogates/donors of gas. The equivalence of these drugs to the gases they are supposed to mimic has not been tested ${ }^{4}$. Some investigators have bubbled gas directly into media, but this precludes adding essential protein to the media due to foaming. Thus, there is a strong need to develop technology that enables the study of both abundant and trace dissolved gases. The system we describe here does these analyses both quantitatively and reproducibly.

A flow culture/assessment system that exposes tissues to precise levels and durations of dissolved gases. We developed a flow culture system according to three fundamental and essential specifications needed to assess effect of gases on tissue: 1. maintain tissue function and viability under continuous flow culture conditions; 2 . continuously monitor parameters that reflect intracellular changes in metabolism in real time; 3. precisely control the aqueous and gas phase composition of the media bathing the tissue. Although there are many systems readily available that have some components needed to investigate effects of dissolved gas, none incorporate all three. Commercially available hypoxia chambers (for instance Baker Ruskinn Cell Culture Workstations) control steady state levels of dissolved gas and have been effectively and most commonly used for hypoxia studies ${ }^{5,6}$. Microfluidics systems have been developed for establishing cell and tissue models where the 3-dimensional structure and cell-to-cell interactions of native tissue can be recreated, which can be used under steady state gas compositions ${ }^{7-9}$. However, neither method is designed for implementing, and assessing real time effects of, rapid changes in dissolved gas concentrations The Seahorse flux analyzer measures $\mathrm{O}_{2}$ consumption rate (OCR) and extracellular acidification rate (mostly from glycolysis and the TCA cycle) on cell monolayers ${ }^{10}$ and has been extensively utilized across many fields. However, it is not designed to maintain tissue in physiological buffers or to control dissolved gas levels.

In previous reports we described an earlier version of our flow culture system and demonstrated its ability to maintain a range of tissues (including islets, retina, liver, brain) over hours and days ${ }^{11-16}$ while continuously assessing metabolic and functional effects of test compounds. This report highlights the incorporation of technology to precisely control both abundant gases (such as $\mathrm{O}_{2}, \mathrm{CO}_{2}$ and $\mathrm{N}_{2}$ ), by using a countercurrent flow device that promotes equilibration between inflow media and premixed gas, and also trace gases, by novel application of permeation tubes. Permeation tubes are commonly used devices for calibration of safety equipment that detect toxic gases such as $\mathrm{CO}$ and $\mathrm{H}_{2} \mathrm{~S}$. They consist of liquified gas housed under pressure in a metal jacket, where the gas continuously leaks through a membrane at a steady and accurately calibrated rate. We present in detail the components and operation of the system in the Methods section, and then illustrate the utility of the system to measure the effects of hypoxia followed by reoxygenation on two tissues, pancreatic islets and retina. We also demonstrate how this device can be used to quantify the effects of $\mathrm{H}_{2} \mathrm{~S}$ on islet function and liver energetics.

Assessment of $\mathrm{O}_{2}$-sensitive processes: $\mathrm{O}_{2}$ consumption rate, reductive state of cytochromes and rate of lactate and pyruvate production. The most direct endpoints with which to assess the acute effects of $\mathrm{O}_{2}$ are components of the electron transport chain (ETC), first and foremost OCR. However, 
bioRxiv preprint doi: https://doi.org/10.1101/2021.03.07.434330; this version posted March 8, 2021. The copyright holder for this preprint (which was not certified by peer review) is the author/funder, who has granted bioRxiv a license to display the preprint in perpetuity. It is made available under aCC-BY 4.0 International license.

Dissolved Gases and Electron Transport

measurements of OCR alone cannot identify the mechanisms that are mediating changes in OCR. Under physiological conditions, OCR can increase in response to changes in substrate supply (increased supply of electrons generated from metabolism) and/or demand (as stimulated by ADP $\left.{ }^{17}\right)^{18}$ (Fig. 1). Metabolism of fuels is reflected by a proportional change in cytochrome reduction and OCR: as the number of electrons bound to cytochromes increase, OCR increases by mass action (a "push" system). In contrast, increased ATP usage by energy-utilizing cell functions (importantly ion flux and biosynthesis) with a corresponding increase in ADP leads to increased OCR, but without increased cytochrome c reduction (a "pull" system) ${ }^{19,20}$. In this way, OCR changes mediated by substrate supply vs. ATP usage can be distinguished, and these fingerprints are informative in understanding mechanisms mediating changes in the ETC induced by $\mathrm{H}_{2} \mathrm{~S}$ and $\mathrm{O}_{2}$.

In addition to regulating ETC activity, $\mathrm{O}_{2}$ can also influence glycolysis (known as the Pasteur effect ${ }^{21}$ ) (Fig. 1). Lactate and pyruvate accumulation and release are determined by relative rates of glycolysis, lactate dehydrogenase (LDH), pyruvate dehydrogenase, mitochondrial and plasma membrane transporters and the redox state of the cytosol. Due to the equilibrium status of $\mathrm{LDH}$, [lactate]/[pyruvate] ratio is proportional to the cytosolic redox state $([\mathrm{NADH}] /[\mathrm{NAD}])^{22}$, so by measuring both lactate and pyruvate, changes in the rate of lactate production rate due to alterations in glycolytic flux vs. cytosolic redox state can be distinguished. The concomitant measurement of $\mathrm{O}_{2}, \mathrm{OCR}$, cytochrome c, cytochrome c oxidase, lactate and pyruvate production provide a comprehensive data set to assess the multitude of biochemical and functional effects of $\mathrm{O}_{2}$ and other gases.

Assessment of $\mathrm{H}_{2} \mathrm{~S}$ effects on insulin secretion rate (ISR) from isolated pancreatic islets. Like $\mathrm{O}_{2}$, $\mathrm{H}_{2} \mathrm{~S}$ also interacts directly with the ETC, where it can be both stimulatory and inhibitory. $\mathrm{H}_{2} \mathrm{~S}$ can inhibit cytochrome c oxidase ${ }^{23}$ and it also can donate electrons to cytochrome $\mathrm{c}^{24}$. However, with respect to pancreatic islets, all previous reports have described only inhibition of ISR ${ }^{25-30}$. Based on the ability of $\mathrm{H}_{2} \mathrm{~S}$ to both increase and decrease ETC activity, we chose to demonstrate the technical caliber of our system by testing the hypothesis that $\mathrm{H}_{2} \mathrm{~S}$ would both stimulate and inhibit ISR depending on its concentration. Flow culture systems are well-suited to measure changes in ISR in response to changes in perifusate composition ${ }^{31}$. Secretogogs that affect ISR by isolated islets including glucose, arginine, amino and fatty acids, acetylcholine, GLP-1 as well as sulfonylureas and GLP-1 analogs, also manifest their effects in vivo. Therefore, isolated islets are a validated and highly relevant model with which to test our flow culture system. To evaluate the commonly asserted assumption that donors of $\mathrm{H}_{2} \mathrm{~S}$ yield the same effects as direct exposure to $\mathrm{H}_{2} \mathrm{~S}$, we also compared the effects of $\mathrm{NaHS}$, a commonly used donor of $\mathrm{H}_{2} \mathrm{~S}$ to direct exposure to dissolved $\mathrm{H}_{2} \mathrm{~S}$. 
Dissolved Gases and Electron Transport

\section{RESULTS}

Measurement of OCR, reduced cytochrome $c$ and ISR by pancreatic islets in the face of changing inflow $\mathrm{O}_{2}$. Ischemia-reperfusion is a stress to tissues that occurs under a range of pathophysiologic conditions, and it is recognized that damage from hypoxia can occur both from the period of decreased energy production and at the time when $\mathrm{O}_{2}$ is replenished. Accordingly, we evaluated the ability of our system to measure the recovery of metabolism and function following a period of decreased $\mathrm{O}_{2}$ levels. Isolated rat islets were placed into the perifusion chamber and perifused for 90 minutes with Krebs-Ringer Bicarbonate buffer containing $3 \mathrm{mM}$ glucose and equilibrated with $21 \% \mathrm{O}_{2} / 5 \% \mathrm{CO}_{2} /$ balance $\mathrm{N}_{2}$. Changes in OCR, cytochrome c reduction state and ISR, were measured in response to increased glucose $(20 \mathrm{mM})$, decreased $\mathrm{O}_{2}$ (by switching to a gas tank supplying the gas equilibration system that contained $3 \%$ for 2 hours), and the return of $\mathrm{O}_{2}$ to $21 \%$ (Fig. 2). To measure OCR, both the inflow and outflow $\mathrm{O}_{2}$ concentrations were measured (Fig. 2A), and the data was then processed by convolution techniques described in the Methods section. After transformation of the inflow $\mathrm{O}_{2}$ using eq. 4 and the transfer function generated with data obtained in the presence of potassium cyanide $(\mathrm{KCN})$ to account for the delay and dispersion of the perifusion chamber, OCR was calculated from eq. 5. As expected, OCR increased with increased glucose concentration, and decreased with lower $\mathrm{O}_{2}$ tension (Fig. 2B). Unexpectedly and notably, there was a transient spike of OCR when $\mathrm{O}_{2}$ in the media was restored. OCR then approached a steady state that was about 55\% of the pre-hypoxic level of OCR. One limitation of the system arises when defining the $\mathrm{O}_{2}$ levels that tissue is exposed to, when in fact there is a gradient from the inflow to the outflow. This uncertainty can be minimized by increasing flow rate thereby decreasing the difference between inflow and outflow concentrations; however, as the difference gets smaller, the resolution of the method decreases.

The reduction state of cytochrome c was concomitantly measured with OCR (Fig. 2B). Previous reports described an equilibrium with respect to the flow of electrons between NADH and cytochrome c 32, 33, and their reductive state represents a balance between the supply of electrons generated by metabolism of fuels and use of electrons to drive proton translocation and ATP production. Consistent with these scenarios, glucose provided more reducing power to drive cytochrome $\mathrm{c}$ to its reduced state (in parallel with OCR), whereas hypoxia favored the reduced state of cytochrome c by slowing its oxidation. Following the return to $21 \% \mathrm{O}_{2}$, cytochrome c reduction reached a steady state of $42 \%$ of the pre-hypoxic levels, consistent with incomplete recovery of OCR. A particularly powerful feature of the systems approach is realized when tissue function can be measured concomitantly with measures of ETC. Fractions were collected during the protocol that were later assayed for insulin (Fig. 2B). Stimulation of ISR by glucose in the presence of $21 \% \mathrm{O}_{2}$ was suppressed in low $\mathrm{O}_{2}$, and ISR recovered to $44 \%$ of its original level of stimulation after reoxygenation.

Measurement of calcium $\left(\mathrm{Ca}^{2+}\right)$ in response to decreased $\mathrm{O}_{2}$ by islets. As fluorescence imaging is a powerful and widely used modality to assess many intracellular signals including but not limited to $\mathrm{Ca}^{2+}$ ${ }^{34}, \mathrm{NADH}^{35,36}$, mitochondrial membrane potential ${ }^{37}$, ATP ${ }^{38}$, and $\mathrm{ROS}^{11}$ in islets, we demonstrated the control of dissolved gas for this modality. We measured the effect of glucose and hypoxia on islet intracellular $\mathrm{Ca}^{2+}$ with a protocol similar to the one we used for OCR except that glucose was lowered back to $3 \mathrm{mM}$ at the end of the experiment (Fig. 2C). As expected, intra-islet $\mathrm{Ca}^{2+}$ increased in response to the increase in glucose. Subsequently, in response to a decrease in $\mathrm{O}_{2}, \mathrm{Ca}^{2+}$ fluorescence rose 3-fold, presumably reflecting a loss of energy-dependent pumping of $\mathrm{Ca}^{2+}$ out of the cells. Notably, in contrast to OCR and ISR parameters, $\mathrm{Ca}^{2+}$ recovered fully to pre-hypoxic levels when $\mathrm{O}_{2}$ was returned to normal levels.

Measurement of lactate/pyruvate production and release by perifused INS-1 832/13 cells in response to changes in $\mathrm{O}_{2}$. To track shifts between glycolytic and mitochondrial energy generation in real time, fractions collected from the outflow were assayed for lactate and pyruvate. We predicted that extracellular 
ratios of these two analytes reflect intracellular regulation of these two compounds. To evaluate this, we measured the response to inhibitors of LDH and mitochondrial transport of pyruvate in INS-1 832/13 cells (henceforth referred to as INS-1 cells). INS-1 cells were used instead of islets because most of the pyruvate made in islets is transported into mitochondria ${ }^{39}$ since they don't have significant capacity for plasma membrane transport of lactate or pyruvate ${ }^{40}$. Oxamate, an inhibitor of LDH, rapidly and completely suppressed lactate release from cells (Fig. 3A), showing the tight relation between production of lactate from LDH and appearance of lactate in the outflow. Somewhat surprisingly, pyruvate did not increase. However, OCR increased suggesting that the decrease in flux from pyruvate to lactate was counterbalanced by an increase in flux of pyruvate into the mitochondria. Blocking transport of pyruvate into mitochondria with zaprinast (a blocker of the mitochondrial pyruvate carrier (MPC) ${ }^{41}$ led to a rapid increase in pyruvate release from cells (Fig. 3B) and diminished OCR. Why lactate production decreased isn't clear from the data but could be explained by a decrease in the cytosolic redox state (NADH/NAD) by the increased activity of the malate/aspartate shuttle. Thus, the rapidity of the changes in lactate and pyruvate production in response to changes in LDH and MPC indicates that membrane transport is fast, and at least in this cell line, extracellular lactate and pyruvate will reflect changes in intracellular events controlling lactate and pyruvate with a time delay of no more than a few minutes. To ensure that this is the case, these experiments would have to be done in whatever tissue is being investigated.

Measurement of OCR, cytochrome c, lactate and pyruvate by perifused retina before and after a period of hypoxia. In order to compare results with islets to those obtained by a tissue that is less sensitive to hypoxia, experiments were carried out on isolated retina, a tissue that normally resides at low $\mathrm{O}_{2}{ }^{16}$. Similar to the measurement in islets, the inflow and outflow $\mathrm{O}_{2}$ were measured (Fig. 4A), and OCR was calculated after convolution of the inflow data. OCR decreased at low $\mathrm{O}_{2}$, and then manifested a transient spike in response to reoxygenation (Fig. 4B). However, in contrast to islets, OCR by retina then approached a much higher recovery (a steady state of $83 \%$ of the pre-hypoxic rate). Reduced cytochrome $\mathrm{c}$ increased to maximal levels during $1 \% \mathrm{O}_{2}$ and stayed at this level throughout the 2 hours of low $\mathrm{O}_{2}$ (Fig. 4B). Consistent with OCR data, upon return of $\mathrm{O}_{2}$ to $21 \%$ cytochrome c reduction recovered to $79 \%$ of pre-hypoxic levels. Comparing post-hypoxia levels of OCR in retina vs. islets (Fig. 4C), islets did not recover from hypoxia as well as retina suggesting that the approach can be used to assess sensitivity to the stress of ischemia-reperfusion conditions. Note that due to the delay in time it took for the inflow perfusate to reach a new equilibrium, the inflow $\mathrm{O}_{2}$ did not reach equilibrium levels with the $\mathrm{O}_{2}$ from the supply gas tank. The levels of $\mathrm{O}_{2}$ in the outflow are dependent upon the inflow $\mathrm{O}_{2}$, the flow rate and the OCR of the tissue in the chamber. In order to match the levels of $\mathrm{O} 2$ that each tissue was exposed to, the supply gas tanks used for the hypoxia phase of the experiments were selected to generate similar outflow $\mathrm{O}_{2}$ levels for the retina ( $1 \%$ yielded an outflow of $6.5 \mathrm{~mm} \mathrm{Hg})$ vs. islets $(3 \%$ yielded $5.5 \mathrm{~mm} \mathrm{Hg})$.

In response to hypoxia, lactate and pyruvate production rates by retina increased, consistent with operation of the Pasteur effect. The ratio of lactate/pyruvate also increased during low $\mathrm{O}_{2}$ conditions (Fig. 4B), reflecting the decreased uptake of pyruvate into the mitochondria, and the increase in the cytosolic redox state (NADH/NAD) that occurs during low $\mathrm{O}_{2}{ }^{42}$. These results provide support for the utility of measuring extracellular lactate and pyruvate for real time responses to events affecting metabolism

Complex time-dependent and concentration-dependent effects of $\mathrm{H}_{2} \mathrm{~S}$ on ISR by islets resolved by fluidics analysis. Past studies on the effect of $\mathrm{H}_{2} \mathrm{~S}$ on ISR were consistent in their findings that $\mathrm{H}_{2} \mathrm{~S}$ was inhibitory 26-30,43-45. However, as $\mathrm{H}_{2} \mathrm{~S}$ has both stimulatory and inhibitory effects on the ETC ${ }^{23,24}$, we predicted that precise titration of the exposure of islets to $\mathrm{H}_{2} \mathrm{~S}$ would reveal stimulatory effects of $\mathrm{H}_{2} \mathrm{~S}$ on ISR. To simplify the analysis and interpretation, we ramped up the $\mathrm{H}_{2} \mathrm{~S}$ concentration in the gas equilibration system (while the inflow and outflow gas ports were clamped) to accumulate $\mathrm{H}_{2} \mathrm{~S}$ until the desired concentration was reached, and then clamped the permeation tube inlet port to maintain that $\mathrm{H}_{2} \mathrm{~S}$ concentration for the indicated times. When $\mathrm{H}_{2} \mathrm{~S}$ was increased until a steady state of $0.44 \mu \mathrm{M}$ was 
reached, ISR from pancreatic islets increased by $35 \%$ relative to ISR at $20 \mathrm{mM}$ glucose (Fig. 5A). The increased ISR was sustained for 3 hours. The effect of $\mathrm{H}_{2} \mathrm{~S}$ was reversible. After purging it from the system, ISR rapidly returned to levels that occurred prior to $\mathrm{H}_{2} \mathrm{~S}$ exposure. In the presence of $3 \mathrm{mM}$ glucose, $\mathrm{H}_{2} \mathrm{~S}$ had no effect on ISR (data not shown), supporting the idea that this reflects a physiologic response of ISR to $\mathrm{H}_{2} \mathrm{~S}$. To demonstrate the ability of the flow system to more fully characterize the timeand concentration-dependency of ISR on $\mathrm{H}_{2} \mathrm{~S}$, we measured ISR at steady state concentrations of $\mathrm{H}_{2} \mathrm{~S}$ from 0.15 to $1.42 \mu \mathrm{M}$. Notably, between 0.33 and $1.42 \mu \mathrm{M} \mathrm{H} \mathrm{H}_{2} \mathrm{~S}$ (Fig. 5B), the initial period of stimulation of ISR (peaking between 1 and 1.5 hours after the start of the ramp of $\mathrm{H}_{2} \mathrm{~S}$ ) was insensitive to the concentration of $\mathrm{H}_{2} \mathrm{~S}$. In contrast, the effect of higher levels of $\mathrm{H}_{2} \mathrm{~S}$ inhibited the ISR rate only between 1.5 and 4 hours following the start of the $\mathrm{H}_{2} \mathrm{~S}$ exposure. The initial upslope of ISR occurred with a delay of about 30 minutes, and both the stimulation and inhibition of ISR were rapidly reversible following the washout of $\mathrm{H}_{2} \mathrm{~S}$ (Fig. 5B). The ability of the system to resolve the time lag for $\mathrm{H}_{2} \mathrm{~S}$ to activate ISR is limited by the rate of the increase of $\mathrm{H}_{2} \mathrm{~S}$ in the gas equilibration system accomplished by the permeation tube. In order to increase the temporal resolution, the permeation tube leak rate can be increased, or the volume of the gas equilibration system must be decreased. Additional concentrations of $\mathrm{H}_{2} \mathrm{~S}$ were tested and the observed peak of ISR, and the steady state level between 3 and 4 hours were plotted as a function of the concentration of $\mathrm{H}_{2} \mathrm{~S}$ (Fig $5 \mathrm{C}$ ), clearly showing the ability of the system to resolve both the time courses and concentration-dependency of the effects of a relatively small range of $\left[\mathrm{H}_{2} \mathrm{~S}\right]$. To test the assumption made in many studies that due to rapid equilibrium between gas donor molecules and their corresponding gas are able to emulate direct exposure to the dissolved gas ${ }^{46}$, we also analyzed the effect of $\mathrm{NaHS}$ on ISR by perifused islets. In contrast to dissolved gaseous $\mathrm{H}_{2} \mathrm{~S}$, low levels of $\mathrm{NaHS}$ had no effect, and higher concentrations $(>10 \mu \mathrm{M})$ only inhibited ISR (Appendix Fig. 1A and 1B) - consistent with findings of all previous studies that used NaHS as an $\mathrm{H}_{2} \mathrm{~S}$ surrogate ${ }^{26-30,43-45}$. Although it is not clear why there is a difference between effects of $\mathrm{H}_{2} \mathrm{~S}$ and NaHS, it may be that the $\mathrm{H}_{2} \mathrm{~S}$ generated by NaHS may diffuse out of solution and into the gas phase when the media traverses the gas equilibration system.

Measurement of OCR, cytochrome c, lactate, and pyruvate by perifused liver slices. We also explored the ability of our flow system to measure effects of $\mathrm{H}_{2} \mathrm{~S}$ on liver by measuring OCR, cytochromes and lactate/pyruvate release by liver slices in the absence and presence of a mitochondrial fuel (succinate). The responses were complex, changed directions in time- and concentration-dependent fashion, and will ultimately require more experiments to interpret the data mechanistically. Therefore, this data was placed in the appendix (Appendix Fig. 2). Nonetheless the waveforms of the responses were clearly resolved, confirmed the capabilities of the multi-parametric detection system, and so were included in this report. The salient features of the data can be summarized by: 1. In the absence of the mitochondrial fuel succinate, $\mathrm{H}_{2} \mathrm{~S}$ changed OCR and reduced cytochromes in proportion to each other, consistent with donation of electrons from $\mathrm{H}_{2} \mathrm{~S}$ to cytochrome $\mathrm{c}^{24}$ (Appendix Fig. 2A); 2. In the presence of a TCA cycle intermediate (succinate), $\mathrm{H}_{2} \mathrm{~S}(2-3 \mu \mathrm{M})$ increased the reductive state of cytochrome c oxidase while decreasing OCR. This is consistent with inhibition of cytochrome c oxidase ${ }^{23}$ (Appendix Fig. 2B), which notably occurred at concentration many times lower than typical estimates of plasma concentration which range from 30-300 $\mu \mathrm{M}^{47}$. At low levels, $\mathrm{H}_{2} \mathrm{~S}$ caused irreversible inhibition of ETC activity upstream of cytochrome c but did not inhibit flow of electrons from succinate. Thus, both reported mechanisms of action of $\mathrm{H}_{2} \mathrm{~S}$ on the ETC were resolved by the system, as well as uncovering additional effects of $\mathrm{H}_{2} \mathrm{~S}$ that had not previously been reported. 
Dissolved Gases and Electron Transport

\section{DISCUSSION}

General features of the flow system. Flow systems have important advantages over static systems for assessment of cell function. Viability and functions of cells and tissues are better and closer to physiological, culture media composition can be changed, and real time production or uptake rates can be quantified from differences between inflow and outflow. Microfluidics devices can maintain tissues in ways that preserve their 3 -dimensional structure and preserve native cell to cell interaction ${ }^{48,49}$. However, these devices will have maximal impact when combined with real time assessment of the tissue as well as the ability to control aqueous and gaseous composition of the media bathing the tissue models. This report focuses on technical modifications to a previously developed flow culture/assessment system ${ }^{50}$ that enables real time measurements of responses of tissues to physiologically important dissolved gases. We achieved this by incorporating a unique gas equilibration system that controls abundant (blood) gases including $\mathrm{O}_{2}, \mathrm{CO}_{2}$ and $\mathrm{N}_{2}$, and by using permeation tubes to introduce and control trace gases such as $\mathrm{H}_{2} \mathrm{~S}$, NO and CO. In this report we demonstrated the utility of this system using both an abundant $\left(\mathrm{O}_{2}\right)$ and a trace gas $\left(\mathrm{H}_{2} \mathrm{~S}\right)$.

Control and effects of dissolved $\mathrm{O}_{2}$ : Recovery of metabolic state following hypoxia and transient response in OCR following reoxygenation. The ability to control dissolved $\mathrm{O}_{2}$ makes our system highly suitable for investigating ischemia-reperfusion injury, generating two informative endpoints from a protocol that measures effects of a short period of low $\mathrm{O}_{2}$ availability followed by return to normal levels. We used the recovery of OCR and cytochrome c reduction to report tissue sensitivity to hypoxia; and we identified a transient spike in OCR that occurs upon reintroduction of normal $\mathrm{O}_{2}$ levels.

The first endpoint characterizes the capacity of a tissue to survive after exposure to selected time periods of low $\mathrm{O}_{2}$. In the illustration carried out in this study, retina recovered to $83 \%$ after hypoxia, whereas islets recovered to only $55 \%$ of pre-hypoxic levels of OCR, corresponding to the two tissue's known sensitivity to oxidative stress. The second endpoint, the burst of OCR occurring when $\mathrm{O}_{2}$ floods back into the cell, is one that has been hypothesized, but has not previously been measured due to the difficulty of measuring OCR in the face of changing $\mathrm{O}_{2}$ levels. Our method has enabled the measurement of transient responses to re-oxygenation and revealed a two-phase waveform in OCR in both islets and retina. The ability to resolve this waveform was dependent on rigorous convolution analysis to remove the delay and dispersion of the $\mathrm{O}_{2}$ signal due to the flow system, combined with ultra-stable and ultrasensitive $\mathrm{O}_{2}$ sensors. It has been long recognized that $\mathrm{ROS}$ is generated rapidly by cells when $\mathrm{O}_{2}$ becomes plentiful after undergoing hypoxic conditions ${ }^{2,3}$. The transient spike of OCR is consistent with a scenario where $\mathrm{O}_{2}$ is the source of oxygen atoms for the ROS. The detailed relationship between OCR and generation of ROS will be the topic of future applications with this system. For instance, the method can be used to test whether slowed re-introduction of $\mathrm{O}_{2}$ or candidate therapeutics including $\mathrm{H}_{2} \mathrm{~S}$, prevent or reduce the transient spike in OCR while at the same time preventing the decreased recovery following the hypoxic period (as has been hypothesized ${ }^{51-54}$ ). The use of this method is timely given the need for optimization of ventilator settings for recovery of hypoxic bouts in COVID-19 patients ${ }^{55}$. Other applications could include: testing whether there are differences in transient OCR response for different tissues or metabolic states; determining the relation of the spike to the response of ROS and recovery/survival of tissue; and testing drugs designed to prevent both the transient spike and/or the decrease in post-hypoxic OCR. The ability to objectively quantify recovery of OCR positions the system to be used to test tissue sensitivity to a wide range of stresses (including ER and oxidative stress, immunological stress (exposure to cytokines), lipotoxicity as well as hypoxia), and to test drugs and treatments designed to increase or decrease recovery from experimentally-induced stresses.

Control and effects of a trace gas: stimulation of ISR by $\mathrm{H}_{2} \mathrm{~S}$ in islets. Trace gas signaling molecules $\left(\mathrm{CO}, \mathrm{NO}, \mathrm{H}_{2} \mathrm{~S}\right)$ are generated in most tissues and have wide-ranging effects on function, metabolism and protection from hypoxia (for reviews ${ }^{56-59}$ ). However, due to the difficulty in quantitatively and 
reproducibly introducing dissolved trace gases into culture media, the majority of studies on these gases have utilized aqueous chemical donors such as $\mathrm{NaHS}$ instead of $\mathrm{H}_{2} \mathrm{~S}$. These surrogates provide only imprecise and uncertain concentrations and timing of tissue exposure to dissolved $\mathrm{H}_{2} \mathrm{~S}$. Due to the extremely accurate calibration of the rate of release of gases, permeation tubes can introduce trace gases into the carrier gas (the mixture of $\mathrm{CO}_{2}-\mathrm{O}_{2}-\mathrm{N}_{2}$ ) present in a gas equilibration system of our perifusion apparatus at exact times and concentrations. Producers of permeation tubes can provide them with a selection of over 500 gases, including $\mathrm{H}_{2} \mathrm{~S}, \mathrm{NO}, \mathrm{CO}$, and ammonia. Thus, the method of incorporating permeation tubes into the gas equilibration system is particularly versatile and can be used for a wide range of applications.

To illustrate the unique advantages of being able to expose tissue to precise levels of dissolved $\mathrm{H}_{2} \mathrm{~S}$, we selected islets as a test tissue since the inhibitory effects of $\mathrm{H}_{2} \mathrm{~S}$ on glucose-stimulated ISR by islets have been described. However, those reports were based on use of the $\mathrm{H}_{2} \mathrm{~S}$ donors $\mathrm{NaHS}$ and $\mathrm{Na}_{2} \mathrm{~S}^{26-30 \text {, }}$ 43-45 and the interpretation that $\mathrm{H}_{2} \mathrm{~S}$ gas is actually delivered to the tissue and at levels low enough to avoid its toxic effects. Moreover, we took note of other studies that suggested that $\mathrm{H}_{2} \mathrm{~S}$ can donate electrons directly to cytochrome $\mathrm{c}^{24}$ and there is evidence that the reduction of cytochrome c may be a key regulatory step in activating ISR ${ }^{34,60}$. Our system bore out this prediction revealing stimulatory effects of $\mathrm{H}_{2} \mathrm{~S}$ on ISR that had not been apparent when exposing islets to a donor of $\mathrm{H}_{2} \mathrm{~S}(\mathrm{NaHS}) . \mathrm{H}_{2} \mathrm{~S}$ at low concentrations (between 0.25 and $0.5 \mu \mathrm{M}$ ) enhances glucose-stimulated ISR, which remained elevated for at least 4 hours. The concentration- and time-dependency were complex however. At higher concentrations of $\mathrm{H}_{2} \mathrm{~S}$ the stimulation of ISR for 90 minutes still occurs, but at later times ISR was inversely proportional to the $\mathrm{H}_{2} \mathrm{~S}$ ranging from a $35 \%$ increase to a $40 \%$ decrease. The range of effects occurred over a relatively small range of $\mathrm{H}_{2} \mathrm{~S}$ concentrations, highlighting the need for the very precise control of dissolved $\mathrm{H}_{2} \mathrm{~S}$ afforded by the use of permeation tubes to investigate this phenomenon. $\mathrm{H}_{2} \mathrm{~S}$ had no effect on ISR at $3 \mathrm{mM}$ glucose, supporting a physiologic mechanism mediating $\mathrm{H}_{2} \mathrm{~S}$ 's effect that may be integrated with glucose sensing and secretory response to fuels by the islet ${ }^{61,62} . \mathrm{H}_{2} \mathrm{~S}$ is generated in islets by the action of 3 intracellular enzymes ${ }^{63}$ but is also a component of blood albeit at levels that are not well established ${ }^{64-66}$. It is notable that the range of concentrations that induced changes in ISR, and above which caused inhibition of OCR in liver are many times lower than typical estimates of plasma concentration which range from $30-300 \mu \mathrm{M}^{47}$. Although it is possible that in vivo, tissue is much less sensitive to $\mathrm{H}_{2} \mathrm{~S}$ than in vitro, it seems more likely that assays that measure plasma $\mathrm{H}_{2} \mathrm{~S}$ result in a significant overestimate coming from related sulfur-containing compounds. The ability to detect differences between responses to $\mathrm{H}_{2} \mathrm{~S}$ and donor molecules, will be useful to the increasing numbers of investigators developing $\mathrm{H}_{2} \mathrm{~S}$ donor molecules as pharmaceutics ${ }^{67,68}$. The increase in ISR in response to $\mathrm{H}_{2} \mathrm{~S}$ has physiological, methodological and clinical implications and the lack of similar stimulatory effects by a donor molecule has broad implications in a field where studies of $\mathrm{NO}, \mathrm{H}_{2} \mathrm{~S}$ and $\mathrm{CO}$ are mostly based on the use of donor molecules.

Lactate and pyruvate: relation to cytosolic events. The assayed values of lactate and pyruvate reflect a number of important specific and global parameters. The rate of release of lactate and pyruvate is an integration of the rate of glycolysis less the amount of pyruvate flux into the mitochondria and traversing gluconeogenesis. Thus, both compounds generally increase in response to glycolytic fuels. Importantly for the study of hypoxia, both metabolites rise in cells when $\mathrm{O}_{2}$ is decreased (the Pasteur effect). In addition, the ratio of cytosolic lactate/pyruvate mirrors the cytosolic NADH/NAD ratio due to the equilibrium status of the $\mathrm{LDH}$ reaction ${ }^{69}$. One could envision that freeze clamping cells and measuring intracellular lactate and pyruvate to directly compare them to the extracellular values could be a way to validate the use of extracellular data. However, in practice, the measurement of intracellular compounds is difficult and also limited by the kinetic resolution of freeze clamping. Instead, we evaluated the responses of the extracellular levels of lactate to a blocker of LDH (oxamate), of pyruvate to a blocker of mitochondrial transport (zaprinast), and both compounds in response to hypoxia. The rapid changes in 
bioRxiv preprint doi: https://doi.org/10.1101/2021.03.07.434330; this version posted March 8, 2021. The copyright holder for this preprint (which was not certified by peer review) is the author/funder, who has granted bioRxiv a license to display the preprint in perpetuity. It is made available under aCC-BY 4.0 International license.

Dissolved Gases and Electron Transport

extracellular lactate and pyruvate supports the rapid redistribution between intra- and extra-cellular compartments, and that real time measurement of extracellular lactate and pyruvate reflect intracellular events governing intracellular lactate and pyruvate. Retina responded to hypoxia with a classical Pasteur effect: low $\mathrm{O}_{2}$ increased lactate, pyruvate and lactate/pyruvate ratio. We envision that the measurement would be especially informative when examining the shift from oxidative to glycolytic metabolism such as seen in tumorigenesis ${ }^{70}$ or stem cell differentiation ${ }^{71}$.

Incorporation of $\mathrm{O}_{2}$-control into a real time fluorescent imaging system. Real time fluorescent imaging is a powerful modality that is commonly used to quantify a wide variety of intracellular compounds and factors while perfusing the optical chamber housing the cells or tissue. Molecular Probes provides intracellular dyes for over 100 separate compounds, so this method is versatile and wide-ranging. Thus, incorporating the gas equilibration system to a flow system providing buffer to a chamber that images of single islets. We observed and quantified clear increases in intracellular $\mathrm{Ca}^{2+}$ in response to hypoxia as metabolic rate decreased. Unexpectedly, the loss of energy and ISR following islet exposure to hypoxia were not accompanied by a loss of glucose-stimulated $\mathrm{Ca}^{2+}$, suggesting the mechanism mediating loss of ISR is independent of $\mathrm{Ca}^{2+}$ signaling. These data are consistent with previous findings that loss of secretory function is more closely associated with bioenergetics than $\mathrm{Ca}^{2+34,72}$. When comparing results of various assays and modes of analysis, the ability to measure multiple endpoints under matched conditions and the same flow system is optimal for systematic study of tissue function.

Summary of uses for the flow culture system. The ability to precisely control the levels and timing of exposure to both abundant and trace gases while measuring multiple parameters in real time on a wide range of tissue and cell models make this system uniquely powerful. The novel resolution of OCR transients attests to the high kinetic resolution of the system. Moreover, stimulatory effects of $\mathrm{H}_{2} \mathrm{~S}$ on ISR not seen in response to a donor molecule attests to the ability of the technology to reveal behavior that provides new insight. Given the wide use of donor molecules in studying gasotransmitters this has broad and significant implications. In addition to enabling users to evaluate direct effects of gases, the method is also suitable for testing conditions or agents that diminish loss of OCR in response to hypoxia- or other stress-induced effects. The use of methods to study the effects of dissolved gas on tissue will impact many areas of fundamental research as well as research of diseases including but not limited to diabetic wound healing, stroke (ischemia/reperfusion injury), COVID-19 and cancer. 


\section{METHODS}

\section{Chemicals}

Krebs-Ringer Bicarbonate buffer was used for all perifusions prepared as described previously ${ }^{12}$. Antimycin A, glucose, oxamate, $\mathrm{KCN}$ and zaprinast were purchased from Sigma-Aldrich. Gases of varying $\mathrm{O}_{2}$ levels $/ 5 \% \mathrm{CO}_{2}$ and balance $\mathrm{N}_{2}$, were purchased from Praxair Distribution Inc (Danbury $\mathrm{CT}$ ). Cytodex and Cytopore beads were purchased from GE healthcare and biosciences (cat no. 17-0448-01 and 17-0911-01, respectively).

\section{Culture of INS-1 $832 / 13$ cells}

INS-1 832/13 cells were kindly provided by Dr. Christopher Newgard and were cultured as previously described $^{73}$. The day before experiments, cells were harvested, and cultured with Cytodex beads $(2.5$ $\mathrm{mg} /$ million cells) for $15 \mathrm{~min}$ in RPMI Media 1640 (Gibco, Grand Island, NY) supplemented with 10\% heat-inactivated fetal bovine serum (Atlanta Biologicals, Lawrenceville, GA), 2 mM L-Glutamine, 1 $\mathrm{mM}$ Pyruvate, $50 \mu \mathrm{M}$ Beta-mercaptoethanol, $20 \mathrm{mM}$ HEPES and 1\% Pen/Strep. They were then washed and cultured overnight in a standard $\mathrm{CO}_{2}$ incubator at 37 degrees $\mathrm{C}$.

\section{Tissue harvesting and processing.}

All procedures were approved by the University of Washington Institutional Animal Care and Use Committee.

Rat islet isolation and culture. Islets were harvested from male Sprague-Dawley rats (approximately $250 \mathrm{~g}$; Envigo/Harlan, Indianapolis, IN) anesthetized by intraperitoneal injection of sodium pentobarbital $(150 \mathrm{mg} / \mathrm{kg}$ rat $)$ ) and purified as described ${ }^{50,74}$. Subsequently, islets were cultured for 18 hours in RPMI Media 1640 supplemented with $10 \%$ heat-inactivated fetal bovine serum (Invitrogen) at $37^{\circ} \mathrm{C}$ prior to the experiments.

Retina isolation. Retinas were harvested from C57BL/6J mice (euthanized by cervical dislocation) ten minutes prior to loading and were dissected into 1/4ths using micro scissors as previously described ${ }^{16}$.

\section{Flow Culture System to maintain tissue with precise control of dissolved gases.}

A flow culture system ${ }^{12}$ was modified to continuously perifuse tissue with buffer equilibrated with the desired composition of dissolved gas using a gas-equilibration system (Fig. 6A and B). Multiple modes of assessment were integrated into the flow culture system and are described below including chemical sensors for $\mathrm{O}_{2}$, spectroscopic analysis of the tissue for measurement of reduced cytochrome $\mathrm{c}$ and cytochrome c oxidase, and collection of outflow fractions for subsequent assay of lactate and pyruvate, or insulin. Model numbers and manufacturers are listed in the legend for Fig. 6. Prior to entering the perifusion chamber, perifusate is pumped from the media reservoirs by an 8-channel peristaltic pump into the thin-walled silastic tubing of the gas equilibration system that facilitated equilibration between the buffer and gas in the glass housing. Selection of media reservoir with desired media composition determined by use of a 6-port valve. To achieve the desired gas composition of $\mathrm{O}_{2}, \mathrm{CO}_{2}$ and $\mathrm{N}_{2}$ within the gas equilibration system, tanks of premixed gases supplied gas to the inflow port, typically $5 \% \mathrm{CO}_{2}$, the desired percentage of $\mathrm{O}_{2}$, and balance $\mathrm{N}_{2}$.

To equilibrate the inflow with desired concentration of $\mathrm{H}_{2} \mathrm{~S}$, we have used devices called permeation tubes (VICI Metronics, Poulsbo WA), an industry standard that provides very precise rates of gas release, typically from 1-30 ug/min. The outlet of the permeation tube was connected to the inlet port of the chamber housing the gas equilibration system (Fig. 6C), so that the head space around the perifusate in the gas-permeable tubing accumulated the trace gas. The concentration in the chamber then increased as a ramp function, rising at a rate equal to the leak rate of the permeation tube $\mathrm{x}$ time divided by the volume 
bioRxiv preprint doi: https://doi.org/10.1101/2021.03.07.434330; this version posted March 8, 2021. The copyright holder for this preprint (which was not certified by peer review) is the author/funder, who has granted bioRxiv a license to display the preprint in perpetuity. It is made available under aCC-BY 4.0 International license.

Dissolved Gases and Electron Transport

of the housing. The amount of dissolved $\mathrm{H}_{2} \mathrm{~S}$ in the buffer was then calculated based on the solubility of $\mathrm{H}_{2} \mathrm{~S}$ in buffer based on Henry's Law:

$\left[\mathrm{H}_{2} \mathrm{~S}_{\mathrm{aq}}\right]=\left[\mathrm{H}_{2} \mathrm{~S}_{\mathrm{g}}\right] \times \mathrm{Hc} / 1000$

Eq. 1

where Henry's constant $\mathrm{Hc}$ is in $0.1 \mathrm{~atm} / \mathrm{M},\left[\mathrm{H}_{2} \mathrm{~S}_{\mathrm{aq}}\right]$ is in $\mu \mathrm{M}$, and $\left[\mathrm{H}_{2} \mathrm{~S}_{\mathrm{g}}\right]$ is in $\mathrm{ng} / \mathrm{mL}$

Lifetime detection of dissolved $\mathrm{O}_{2} . \mathrm{O}_{2}$ tension in the inflow and outflow buffer was measured by detecting the phosphorescence lifetime of an $\mathrm{O}_{2}$-sensitive dye painted on the inside of the perifusion chamber using a MFPF-100 multifrequency phase fluorometer lifetime measurement system (TauTheta Instruments, Boulder, $\mathrm{CO}$ ) as previously described ${ }^{75}$. Using tanks of gas containing varying amounts of $\mathrm{O}_{2}(21,15,10,5,3,1$ or $0 \%)$, data was generated that showed the dependency of the lifetime signal as a function of $\mathrm{O}_{2}$ and the rapidity of changes in $\mathrm{O}_{2}$ after each change in gas tank. Within 5 minutes, $\mathrm{O}_{2}$ achieves $95 \%$ of steady state levels (Fig. 7A), where the delay is primarily due to time needed for the gas in the gas equilibration system to turnover as the actual sensor responds in microseconds. The $\mathrm{O}_{2}$ dependency of the dye signal conformed to the Stern-Volmer equation

Lifetime $=1 /\left(\mathrm{k}_{1}+\mathrm{k}_{\mathrm{q}} *\left[\mathrm{O}_{2}\right]^{1 / 2}\right)$

Eq. 2

where lifetime is in usec. Equation 2 was used to as a calibration curve to convert the optical signals to $\mathrm{O}_{2}$ content (Fig 7B). The use of lifetime detection produces very stable and sensitive data at both normal (Fig. 7C) and low (Fig. 7D) $\mathrm{O}_{2}$ levels producing $\mathrm{S} / \mathrm{N}$ over 20 even when measuring a change of only 1.9 $\mathrm{mm} \mathrm{Hg}$.

\section{Continuous measurement of OCR.}

Measuring the difference between inflow and outflow during invariant inflow $\mathrm{O}_{2}$. When inflow $\mathrm{O}_{2}$ tension is constant, OCR by the tissue equals the difference between the content of $\mathrm{O}_{2}$ flowing into the perifusion chamber minus that flowing out time the flow rate as follows.

$\mathrm{OCR}=\left(\left[\mathrm{O}_{2}\right]\right.$ in $-\left[\mathrm{O}_{2}\right]$ out $) \times$ flow rate

Eq. 3

where flow rate is in $\mathrm{uL} / \mathrm{min}$ and $\left[\mathrm{O}_{2}\right]$ is in $\mathrm{nmol} / \mathrm{mL}$. Inflow and outflow $\mathrm{O}_{2}$ sensors were positioned on the inside of the perifusion chamber $2 \mathrm{~cm}$ upstream and $2 \mathrm{~cm}$ downstream from the tissue, respectively. Perifusate flow rates were set to result in a difference between inflow and outflow $\mathrm{O}_{2}$ of between 5 and $25 \%$ of the baseline $\mathrm{O}_{2}$ signal, so it was large enough to be accurately measured, but small enough to avoid exposure to unintended hypoxic conditions.

Measuring OCR during changes in inflow $\mathrm{O}_{2}$ : convolution analysis to remove system effects. Measuring the temporal changes in OCR by tissue in the face of changing inflow concentrations of $\mathrm{O}_{2}$ requires a correction for the difference in inflow and outflow $\mathrm{O}_{2}$ levels due to the delay and dispersion generated between the inflow and outflow sensors. To calculate OCR from equation 3 in the face of changing inflow $\mathrm{O}_{2}$, the inflow $\mathrm{O}_{2}$ content must be converted to what it would be if the sensor was located at the outflow sensor location. This was done with classical convolution methods ${ }^{76}$ with mild regularization ${ }^{77}$ to create a mathematical function representing the delay and dispersion of the inflow signal by the flow through the perifusion chamber from the inflow to the outflow sensor described numerically by equation 4 .

$\left[\mathrm{O}_{2}\right]_{\text {in:transformed }}=\left[\mathrm{O}_{2}\right]_{\text {in }} * \mathrm{~h}(\mathrm{t})$

Eq. 4 
where $\left[\mathrm{O}_{2}\right]_{\text {in:transformed }}$ is the inflow concentration at the outflow sensor, and $\mathrm{h}(\mathrm{t})$ was the system transfer function. In the absence of tissue in the flow system, $\mathrm{O}_{2}$ was decreased to hypoxic levels in the same protocol as was done in the presence of tissue, while measuring $\left[\mathrm{O}_{2}\right]$ in the inflow and outflow (Fig. 8). The transfer function $\mathrm{h}(\mathrm{t})$ was then generated for each experimental condition by solving equation 4 by deconvolution using MatLab. For each perifusion analysis, the measured $\left[\mathrm{O}_{2}\right]_{\text {in }}$ was converted to $\left[\mathrm{O}_{2}\right]_{\text {in:transformed }}$ by convolution with the transfer function (also using MatLab) and OCR was calculated from

$\mathrm{OCR}=\left(\left[\mathrm{O}_{2}\right]_{\text {in:transformed }}-\left[\mathrm{O}_{2}\right]_{\text {out }}\right) \times$ FR

Eq. 5

For the protocols in this experimental set-up, only 35 minutes of the transfer function was needed to accurately transform the inflow $\left[\mathrm{O}_{2}\right]$.

\section{Measurement of cytochrome c and cytochrome c oxidase reduction.}

The reductive states of cytochrome $\mathrm{c}$ and cytochrome $\mathrm{c}$ oxidase were measured by light transmission at 550 and $605 \mathrm{~nm}$ respectively through the column of islets or tissue as previously described ${ }^{60,78}$. Due to the low signal to noise and baseline shift during the experiments, direct measurement of absorption was not stable. To better resolve changes in the reduced state of cytochromes the second derivative of the absorbance spectra with respect to wavelength was calculated ${ }^{79}$. Like absorption, this parameter reflects the number of electrons bound to the cytochrome as well as the amount of protein. However, the second derivative is unaffected by shifts in baseline allowing resolution of real time changes in absorbance. At the conclusion of each experiment, calibration spectra for fully oxidized and reduced cytochromes were acquired in the presence of blockers of the ETC - namely $12 \mathrm{ug} / \mathrm{ml}$ antimycin to stop the flow of electrons to cytochromes, followed by $3 \mathrm{mM} \mathrm{KCN}$ to facilitate the maximal accumulation of electrons bound to cytochromes.

Spectral data processing. The second derivative of absorbance with respect to wavelength ${ }^{79}$ at 550 and $605 \mathrm{~nm}$ was calculated as

$$
\mathrm{A} b s^{\prime}=\frac{\Delta\left(\frac{\Delta \mathrm{Abs}}{\Delta v}\right)}{\Delta v}
$$

where $\mathrm{Abs}=\log ($ intensity - intensitybkg $) /($ intensityref - intensitybkg $), v=$ wavelength in nanometers, and $\Delta=$ change in the variable over the integration interval. Background intensity (intensitybkg) was determined

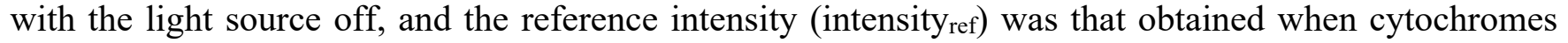
were fully oxidized by antimycin A. Percent reduction of cytochromes were calculated following Kashiwagura et al. ${ }^{80}$ as

Cytochrome $_{\text {red }}=100 \times \frac{A b s^{\prime \prime}-A b s_{a A}^{\prime \prime}}{A b s_{K C N}^{\prime \prime}-A b s_{a A}^{\prime \prime}}$

where Abs" and Abs" ${ }_{\mathrm{KCN}}$ are values at 550 or $605 \mathrm{~nm}$, and Abs" ${ }_{\mathrm{KCN}}$ and Abs" ${ }_{\mathrm{aA}}$ is obtained in the presence of $\mathrm{KCN}$ and antimycin A corresponding to when cytochrome $\mathrm{c}$ and cytochrome c oxidase are fully reduced or oxidized.

Assays for lactate, pyruvate and insulin.

Fractions collected during experiments were subsequently assayed for lactate, pyruvate or insulin. Insulin was measured by RIA, and lactate and pyruvate were measured using colorimetric assays using kits per manufacturer's instructions (insulin, Cat no. RI-13K, Millipore Sigma, Burlington, MA; lactate, 
bioRxiv preprint doi: https://doi.org/10.1101/2021.03.07.434330; this version posted March 8, 2021. The copyright holder for this preprint (which was not certified by peer review) is the author/funder, who has granted bioRxiv a license to display the preprint in perpetuity. It is made available under aCC-BY 4.0 International license.

Dissolved Gases and Electron Transport

Cat no. A22189, Invitrogen, Carlsbad, CA; pyruvate, Cat no. MAK332, Sigma Aldrich). Amounts of lactate, pyruvate and insulin in inflow samples were insignificant, so rates of production were calculated as the concentration in the outflow times the flow rate and normalized by the amount of tissue.

\section{Imaging and quantification of cytosolic $\mathrm{Ca}^{2+}$.}

Cytosolic $\mathrm{Ca}^{2+}$ was measured by fluorescence imaging of islets after loading them with Fura-2 AM (Invitrogen) as previously described ${ }^{81}$. The perifusion system described above was used to supply buffer with the specified gas composition to a temperature-controlled, 250- $\mu$ l perifusion dish (Bioptechs, Butler, PA) that was mounted on to the stage of a Nikon Eclipse TE-200 inverted microscope. Results are displayed as the ratio of the fluorescent intensities during excitation at two wavelengths (F340/F380).

\section{Statistical Analysis.}

When the message to be conveyed by the graph was an illustration of the high resolution and low noise of the data that was generated by the method, then single experiments were shown as indicated, for instance for OCR in response to hypoxia. In most instances, to demonstrate the reproducibility of the data, technical replicates were conducted and the data averaged - i.e. multiple perifusion channels were run in parallel with pooled tissue or cells batches from multiple animals or flasks of cells. When the goal was to test and show a biological effect, multiple runs were done on different days (for instance comparison of retina and islet recovery of OCR following hypoxia) and statistical significance was determined using Student's t tests carried out with Microsoft Excel (Redmond, WA). With either technical or biological replicates, error bars on time courses were calculated as the average $+/-$ the SE (calculated as $\mathrm{SD} / \mathrm{n}^{1 / 2}$ ). Raw data for all experiments is compiled into an Excel spreadsheet and saved as a source file. 


\section{ACKNOWLEDGEMENTS}

This research was funded by grants from the National Institutes of Health (DK17047) and the National Science Foundation (STTR Phase 2, 1853066). Special thanks to VICI Metronics for providing custommade permeation tubes.

\section{AUTHOR CONTRIBUTIONS}

IRS devised the methods and designed the experiments with contributions for retinal experiments from JBH. JK contributed to the incorporation of permeation tubes into the gas equilibrium system. VK, BMR and SRJ performed the experiments; KPB developed the data processing algorithms for calculation of OCR; IRS conceived the study and wrote the manuscript with helpful feedback from JBH. All authors read and commented on the final manuscript. 
bioRxiv preprint doi: https://doi.org/10.1101/2021.03.07.434330; this version posted March 8, 2021. The copyright holder for this preprint

(which was not certified by peer review) is the author/funder, who has granted bioRxiv a license to display the preprint in perpetuity. It is made available under aCC-BY 4.0 International license.

Dissolved Gases and Electron Transport

\section{REFERENCES}

1. Prabhakar, N.R. \& Semenza, G.L. Gaseous messengers in oxygen sensing. J Mol Med (Berl) 90, 265-272 (2012).

2. Chouchani, E.T. et al. A Unifying Mechanism for Mitochondrial Superoxide Production during Ischemia-Reperfusion Injury. Cell Metab 23, 254-263 (2016).

3. Zweier, J.L., Flaherty, J.T. \& Weisfeldt, M.L. Direct measurement of free radical generation following reperfusion of ischemic myocardium. Proc Natl Acad Sci U S A 84, 1404-1407 (1987).

4. Chen, Y., Zhang, F., Yin, J., Wu, S. \& Zhou, X. Protective mechanisms of hydrogen sulfide in myocardial ischemia. J Cell Physiol 235, 9059-9070 (2020).

5. Jaakkola, P. et al. Targeting of HIF-alpha to the von Hippel-Lindau ubiquitylation complex by O2-regulated prolyl hydroxylation. Science 292, 468-472 (2001).

6. Epstein, A.C. et al. C. elegans EGL-9 and mammalian homologs define a family of dioxygenases that regulate HIF by prolyl hydroxylation. Cell 107, 43-54 (2001).

7. Ren, L. et al. Investigation of hypoxia-induced myocardial injury dynamics in a tissue interface mimicking microfluidic device. Anal Chem 85, 235-244 (2013).

8. Manafi, N. et al. Organoids and organ chips in ophthalmology. Ocul Surf 19, 1-15 (2020).

9. Kimura, H., Sakai, Y. \& Fujii, T. Organ/body-on-a-chip based on microfluidic technology for drug discovery. Drug Metab Pharmacokinet 33, 43-48 (2018).

10. Wu, M. et al. Multiparameter metabolic analysis reveals a close link between attenuated mitochondrial bioenergetic function and enhanced glycolysis dependency in human tumor cells. Am J Physiol Cell Physiol 292, C125-136 (2007).

11. Neal, A. et al. Real-time imaging of intracellular hydrogen peroxide in pancreatic islets. Biochem $J$ 473, 4443-4456 (2016).

12. Neal, A. et al. Quantification of Low-Level Drug Effects Using Real-Time, in vitro Measurement of Oxygen Consumption Rate. Toxicological sciences : an official journal of the Society of Toxicology 148, 594-602 (2015).

13. Gilbert, M., Jung, S.R., Reed, B.J. \& Sweet, I.R. Islet oxygen consumption and insulin secretion tightly coupled to calcium derived from L-type calcium channels but not from the endoplasmic reticulum. J Biol Chem 283, 24334-24342 (2008).

14. Sweet, I.R. et al. Endothelial inflammation induced by excess glucose is associated with cytosolic glucose 6-phosphate but not increased mitochondrial respiration. Diabetologia 52, 921931 (2009).

15. Weydt, P. et al. Thermoregulatory and metabolic defects in Huntington's disease transgenic mice implicate PGC-1alpha in Huntington's disease neurodegeneration. Cell Metab (2006).

16. Bisbach, C.M. et al. Succinate Can Shuttle Reducing Power from the Hypoxic Retina to the O2Rich Pigment Epithelium. Cell Rep 31, 107606 (2020).

17. Chance, B. \& Williams, G.R. The respiratory chain and oxidative phosphorylation. Adv Enzymol Relat Subj Biochem 17, 65-134 (1956).

18. Wilson, D.F., Owen, C.S. \& Erecinska, M. Quantitative dependence of mitochondrial oxidative phosphorylation on oxygen concentration: a mathematical model. Arch Biochem Biophys 195, 494-504 (1979).

19. Brown, G.C. Control of respiration and ATP synthesis in mammalian mitochondria and cells. Biochem J 284 ( Pt 1), 1-13 (1992).

20. Sweet, I.R. \& Gilbert, M. Contribution of calcium influx in mediating glucose-stimulated oxygen consumption in pancreatic islets. Diabetes 55, 3509-3519 (2006).

21. Krebs, H.A. The Pasteur effect and the relations between respiration and fermentation. Essays Biochem 8, 1-34 (1972). 
bioRxiv preprint doi: https://doi.org/10.1101/2021.03.07.434330; this version posted March 8, 2021. The copyright holder for this preprint

(which was not certified by peer review) is the author/funder, who has granted bioRxiv a license to display the preprint in perpetuity. It is made available under aCC-BY 4.0 International license.

Dissolved Gases and Electron Transport

22. Williamson, D.H., Lund, P. \& Krebs, H.A. The redox state of free nicotinamide-adenine dinucleotide in the cytoplasm and mitochondria of rat liver. Biochem J 103, 514-527 (1967).

23. Khan, A.A. et al. Effects of hydrogen sulfide exposure on lung mitochondrial respiratory chain enzymes in rats. Toxicol Appl Pharmacol 103, 482-490 (1990).

24. Vitvitsky, V. et al. Cytochrome c Reduction by H2S Potentiates Sulfide Signaling. ACS Chem Biol 13, 2300-2307 (2018).

25. Ali, M.Y., Whiteman, M., Low, C.M. \& Moore, P.K. Hydrogen sulphide reduces insulin secretion from HIT-T15 cells by a KATP channel-dependent pathway. J Endocrinol 195, 105112 (2007).

26. Niki, I. \& Kaneko, Y. [H2S production by L-cysteine metabolism inhibits insulin release]. Nihon Yakurigaku Zasshi 128, 214-218 (2006).

27. Wu, L. et al. Pancreatic islet overproduction of H2S and suppressed insulin release in Zucker diabetic rats. Lab Invest 89, 59-67 (2009).

28. Yang, W., Yang, G., Jia, X., Wu, L. \& Wang, R. Activation of KATP channels by H2S in rat insulin-secreting cells and the underlying mechanisms. J Physiol 569, 519-531 (2005).

29. Beltowski, J., Wojcicka, G. \& Jamroz-Wisniewska, A. Hydrogen sulfide in the regulation of insulin secretion and insulin sensitivity: Implications for the pathogenesis and treatment of diabetes mellitus. Biochem Pharmacol 149, 60-76 (2018).

30. Tang, G., Zhang, L., Yang, G., Wu, L. \& Wang, R. Hydrogen sulfide-induced inhibition of Ltype Ca2+ channels and insulin secretion in mouse pancreatic beta cells. Diabetologia 56, 533541 (2013).

31. Lacy, P.E., Walker, M.M. \& Fink, C.J. Perifusion of isolated rat islets in vitro. Participation of the microtubular system in the biphasic release of insulin. Diabetes 21, 987-998 (1972).

32. Wilson, D.F., Stubbs, M., Oshino, N. \& Erecinska, M. Thermodynamic relationships between the mitochondrial oxidation-reduction reactions and cellular ATP levels in ascites tumor cells and perfused rat liver. Biochemistry 13, 5305-5311 (1974).

33. Wilson, D.F., Stubbs, M., Veech, R.L., Erecinska, M. \& Krebs, H.A. Equilibrium relations between the oxidation-reduction reactions and the adenosine triphosphate synthesis in suspensions of isolated liver cells. Biochem J 140, 57-64 (1974).

34. Rountree, A.M. et al. Control of insulin secretion by cytochrome $\mathrm{C}$ and calcium signaling in islets with impaired metabolism. J Biol Chem 289, 19110-19119 (2014).

35. Bennett, B.D., Jetton, T.L., Ying, G., Magnuson, M.A. \& Piston, D.W. Quantitative subcellular imaging of glucose metabolism within intact pancreatic islets. J Biol Chem 271, 3647-3651 (1996).

36. Pedersen, M.G., Mosekilde, E., Polonsky, K.S. \& Luciani, D.S. Complex patterns of metabolic and $\mathrm{Ca}(2)(+)$ entrainment in pancreatic islets by oscillatory glucose. Biophys $J \mathbf{1 0 5}, 29-39$ (2013).

37. Pertusa, J.A. et al. Increased glucose sensitivity of stimulus-secretion coupling in islets from Psammomys obesus after diet induction of diabetes. Diabetes 51, 2552-2560 (2002).

38. Hodson, D.J. et al. Incretin-modulated beta cell energetics in intact islets of Langerhans. Mol Endocrinol 28, 860-871 (2014).

39. MacDonald, M.J. Elusive proximal signals of beta-cells for insulin secretion. Diabetes 39, 14611466 (1990).

40. Ishihara, H. \& Wollheim, C.B. What couples glycolysis to mitochondrial signal generation in glucose-stimulated insulin secretion? IUBMB Life 49, 391-395 (2000).

41. Du, J. et al. Inhibition of mitochondrial pyruvate transport by zaprinast causes massive accumulation of aspartate at the expense of glutamate in the retina. J Biol Chem 288, 3612936140 (2013). 
bioRxiv preprint doi: https://doi.org/10.1101/2021.03.07.434330; this version posted March 8, 2021. The copyright holder for this preprint

(which was not certified by peer review) is the author/funder, who has granted bioRxiv a license to display the preprint in perpetuity. It is made available under aCC-BY 4.0 International license.

Dissolved Gases and Electron Transport

42. Lai, F.M. \& Miller, A.T., Jr. Cytoplasmic and mitochondrial NAD + -NADH 2 ratios in rat brain and liver: effect of hypoxia. Comp Biochem Physiol B 44, 829-835 (1973).

43. Lu, A., Chu, C., Mulvihill, E., Wang, R. \& Liang, W. ATP-sensitive K(+) channels and mitochondrial permeability transition pore mediate effects of hydrogen sulfide on cytosolic $\mathrm{Ca}(2+)$ homeostasis and insulin secretion in beta-cells. Pflugers Arch 471, 1551-1564 (2019).

44. Patel, M. \& Shah, G. Possible role of hydrogen sulfide in insulin secretion and in development of insulin resistance. J Young Pharm 2, 148-151 (2010).

45. Yang, G., Yang, W., Wu, L. \& Wang, R. H2S, endoplasmic reticulum stress, and apoptosis of insulin-secreting beta cells. J Biol Chem 282, 16567-16576 (2007).

46. Li, Q. \& Lancaster, J.R., Jr. Chemical foundations of hydrogen sulfide biology. Nitric Oxide 35, 21-34 (2013).

47. Olson, K.R. Is hydrogen sulfide a circulating "gasotransmitter" in vertebrate blood? Biochim Biophys Acta 1787, 856-863 (2009).

48. Nieskens, T.T. \& Wilmer, M.J. Kidney-on-a-chip technology for renal proximal tubule tissue reconstruction. Eur J Pharmacol 790, 46-56 (2016).

49. Rothbauer, M., Zirath, H. \& Ertl, P. Recent advances in microfluidic technologies for cell-to-cell interaction studies. Lab Chip 18, 249-270 (2018).

50. Sweet, I.R. et al. Regulation of ATP/ADP in pancreatic islets. Diabetes 53, 401-409 (2004).

51. Clark, E.T. \& Gewertz, B.L. Limiting oxygen delivery attenuates intestinal reperfusion injury. $J$ Surg Res 53, 485-489 (1992).

52. Zhang, P. et al. Role of Hydrogen Sulfide in Myocardial Ischemia-Reperfusion Injury. $J$ Cardiovasc Pharmacol (2020).

53. Citi, V. et al. The Role of Hydrogen Sulfide and H2S-donors in Myocardial Protection Against Ischemia/Reperfusion Injury. Curr Med Chem 25, 4380-4401 (2018).

54. Du, J., Jin, H. \& Yang, L. Role of Hydrogen Sulfide in Retinal Diseases. Front Pharmacol 8, 588 (2017).

55. Eastwood, G.M. \& Nichol, A. Optimal ventilator settings after return of spontaneous circulation. Curr Opin Crit Care 26, 251-258 (2020).

56. Ahmad, A. et al. Role of Nitric Oxide in the Cardiovascular and Renal Systems. Int J Mol Sci 19 (2018).

57. Beltowski, J. Synthesis, Metabolism, and Signaling Mechanisms of Hydrogen Sulfide: An Overview. Methods Mol Biol 2007, 1-8 (2019).

58. Cheng, Y. \& Rong, J. Therapeutic Potential of Heme Oxygenase-1/carbon Monoxide System Against Ischemia-Reperfusion Injury. Curr Pharm Des 23, 3884-3898 (2017).

59. Krylatov, A. et al. The Role of Reactive Oxygen Species, Kinases, Hydrogen Sulfide, and Nitric Oxide in the Regulation of Autophagy and Their Impact on Ischemia and Reperfusion Injury in the Heart. Curr Cardiol Rev (2020).

60. Jung, S.R. et al. Reduced cytochrome $C$ is an essential regulator of sustained insulin secretion by pancreatic islets. J Biol Chem 286, 17422-17434 (2011).

61. Prentki, M., Matschinsky, F.M. \& Madiraju, S.R. Metabolic signaling in fuel-induced insulin secretion. Cell Metab 18, 162-185 (2013).

62. Campbell, J.E. \& Newgard, C.B. Mechanisms controlling pancreatic islet cell function in insulin secretion. Nature reviews. Molecular cell biology (2021).

63. Kimura, H. Hydrogen sulfide: from brain to gut. Antioxid Redox Signal 12, 1111-1123 (2010).

64. Whiteman, M. et al. Adiposity is a major determinant of plasma levels of the novel vasodilator hydrogen sulphide. Diabetologia 53, 1722-1726 (2010).

65. Karunya, R. et al. Rapid measurement of hydrogen sulphide in human blood plasma using a microfluidic method. Sci Rep 9, 3258 (2019). 
bioRxiv preprint doi: https://doi.org/10.1101/2021.03.07.434330; this version posted March 8, 2021. The copyright holder for this preprint

(which was not certified by peer review) is the author/funder, who has granted bioRxiv a license to display the preprint in perpetuity. It is made available under aCC-BY 4.0 International license.

Dissolved Gases and Electron Transport

66. Whitfield, N.L., Kreimier, E.L., Verdial, F.C., Skovgaard, N. \& Olson, K.R. Reappraisal of $\mathrm{H} 2 \mathrm{~S} /$ sulfide concentration in vertebrate blood and its potential significance in ischemic preconditioning and vascular signaling. Am J Physiol Regul Integr Comp Physiol 294, R19301937 (2008).

67. Citi, V. et al. Anti-inflammatory and antiviral roles of hydrogen sulfide: Rationale for considering H2 S donors in COVID-19 therapy. Br J Pharmacol 177, 4931-4941 (2020).

68. Testai, L., Citi, V., Martelli, A., Brogi, S. \& Calderone, V. Role of hydrogen sulfide in cardiovascular ageing. Pharmacol Res 160, 105125 (2020).

69. Newsholme, E. \& Start, C. Regulation in Metabolism. (John Wiley and Sons, London; 1973).

70. de Groof, A.J. et al. Increased OXPHOS activity precedes rise in glycolytic rate in HRasV12/E1A transformed fibroblasts that develop a Warburg phenotype. Mol Cancer 8, 54 (2009).

71. Zhou, W. et al. HIF1alpha induced switch from bivalent to exclusively glycolytic metabolism during ESC-to-EpiSC/hESC transition. EMBO J 31, 2103-2116 (2012).

72. Rountree, A.M. et al. Loss of coupling between calcium influx, energy consumption and insulin secretion associated with development of hyperglycaemia in the UCD-T2DM rat model of type 2 diabetes. Diabetologia 56, 803-813 (2013).

73. Hohmeier, H.E. et al. Isolation of INS-1-derived cell lines with robust ATP-sensitive K+ channel-dependent and -independent glucose-stimulated insulin secretion. Diabetes 49, 424-430 (2000).

74. Matsumoto, S., Shibata, S. \& Kirchhof, N. Immediate reversal of diabetes in primates following intraportal transplantation of porcine islets purified on a new histidine-lactobionate-iodixanol gradient. Transplantation 67, S220 (1999).

75. Sweet, I.R. et al. Continuous measurement of oxygen consumption by pancreatic islets. Diabetes Technol Ther 4, 661-672 (2002).

76. Weigle, D.S., Sweet, I.R. \& Goodner, C.J. A kinetic analysis of hepatocyte responses to a glucagon pulse: mechanism and metabolic consequences of differences in response decay times. Endocrinology 121, $732-737$ (1987).

77. Bube, K.P. \& Langan, R.T. A continuation approach to regularization of ill-posed problems with application to cross-well traveltime tomography. Geophysics 73, VE337-VE351 (2008).

78. Chance, B. \& Williams, G.R. Respiratory enzymes in oxidative phosphorylation. VI. The effects of adenosine diphosphate on azide-treated mitochondria. J Biol Chem 221, 477-489 (1956).

79. Cavinato, A.G., Mayes, D.M., Ge, Z.H. \& Callis, J.B. Noninvasive method for monitoring ethanol in fermentation processes using fiber-optic near-infrared spectroscopy. Anal Chem 62, 1977-1982 (1990).

80. Kashiwagura, T., Wilson, D.F. \& Erecinska, M. Oxygen dependence of cellular metabolism: the effect of $\mathrm{O} 2$ tension on gluconeogenesis and urea synthesis in isolated rat hepatocytes. $J$ Cell Physiol 120, 13-18 (1984).

81. Jung, S.R., Reed, B.J. \& Sweet, I.R. A highly energetic process couples calcium influx through L-type calcium channels to insulin secretion in pancreatic beta-cells. Am J Physiol Endocrinol Metab 297, E717-727 (2009). 


\section{FIGURE LEGENDS}

Fig. 1. Direct control of OCR: Energy Supply vs Energy Demand vs O2. Schematic depicting three mechanisms mediating OCR. 1: the supply of reduced electrons generated by metabolism of fuel. 2: the usage of ATP by energy-utilizing cellular function yielding ADP (a major regulator of OCR). 3: the concentration of dissolved $\mathrm{O}_{2}$. The concomitant measurement of reduced cytochromes and $\mathrm{O}_{2}$ allows for the distinction between the three mechanisms mediating observed changes in OCR. The vertical arrows depict the changes that are acutely affected by changes in $\mathrm{O}_{2}$. Low $\mathrm{O}_{2}$ leads to increased reductive state of cytochrome $\mathrm{c}$ and cytochrome $\mathrm{c}$ oxidase, decreased OCR. In some tissue types, the decrease in ATP production by oxidative phosphorylation is compensated by increased ATP generation from glycolysis (the Pasteur effect).

Fig. 2. Effect of glucose and low $\mathrm{O}_{2}$ on transient and steady state ETC, and ISR and intracellular $\mathbf{C a}^{2+}$ in pancreatic islets. Islets $(900 /$ channel) were handpicked with a P200 pipet and after mixing with Cytodex beads ( $1 \mathrm{uL} / 10$ islets) loaded into the perifusion chamber, and the flow rate was set to $150 \mathrm{uL} / \mathrm{min}$ with Krebs-Ringer Bicarbonate buffer containing $3 \mathrm{mM}$ glucose for $90 \mathrm{~min}$. At time $=0$, glucose concentration was raised to $20 \mathrm{mM}$ for $45 \mathrm{~min}$; subsequently, $\mathrm{O}_{2}$ was decreased to $3 \%$ for 2 hours, and then returned to $21 \%$. A. The protocol generated inflow and outflow $\mathrm{O}_{2}$ profiles such as shown. Following the completion of the protocol, $12 \mu \mathrm{g} / \mathrm{ml}$ antimycin A (aA) was added for 25 minutes, and then $3 \mathrm{mM}$ $\mathrm{KCN}$, and the hypoxia protocol was repeated while islet respiration was suppressed in order to characterize delay and dispersion due to the separation in space of inflow and outflow sensors. B. Calculated values of OCR (representative data from an $\mathrm{n}$ of 3 (average recovery $=0.55+/-0.07$ ), reduced cytochrome $\mathrm{c}(\mathrm{n}$ $=2)$, and ISR $(n=2)$ were plotted as described in the Methods section. C. In a separate illustrative experiment, intracellular $\mathrm{Ca}^{2+}$ in islets was imaged and quantified using the same protocol except glucose was also decreased back to $3 \mathrm{mM}$ glucose at the end of the experiment.

Fig. 3. Effect of glucose and inhibitors of LDH and MPC on OCR, lactate and pyruvate production rate by INS-1 832/13 cells. A. The effects of glucose and then oxamate (50 mM, an inhibitor of LDH) on OCR, lactate production rate and pyruvate production rate at the times indicated in the figure were measured. B. The effects of glucose and then zaprinast $(200 \mu \mathrm{M}$, an inhibitor of MPC) on OCR, lactate production rate and pyruvate production rate. Data for both plots are the average $+/-\mathrm{SE}, \mathrm{n}=2$ ).

Fig. 4. Effect of low $\mathrm{O}_{2}$ on transient and steady state ETC, and lactate/pyruvate in isolated retina. A. Four retinas (16 pieces) per chamber were loaded into the flow chamber, where each group of 4 retinal pieces were separated by a 3-uL layer of Cytodex beads. The tissue was sandwiched on the top and bottom by $50 \mathrm{uL}$ of Cytopore beads and both layers were held in place with a porous frit (Interstate Specialty Products, Suton, MA, Cat no. POR 4894, cut to $4.2 \mathrm{~mm}$ diameter and 0.25 in long). Ninety minutes after loading the retina into the system (flow rate $=130 \mathrm{uL} / \mathrm{min}$ ), the $\mathrm{O}_{2}$ tank was switched one containing $1 \%$ $\mathrm{O}_{2}$ for 2 hours, and subsequently returned to $21 \%$. A. The protocol generated inflow and outflow $\mathrm{O}_{2}$ profiles such as shown. Following the completion of the protocol, $12 \mathrm{vg} / \mathrm{ml}$ antimycin A (aA) was added for 20 minutes, and then $3 \mathrm{mM} \mathrm{KCN}$, and the hypoxia protocol was repeated while retinal respiration was suppressed in order to characterize delay and dispersion due to the separation in space of inflow and outflow sensors. B. Measurements of OCR (representative data from an $\mathrm{n}$ of 6 (average recovery $=0.83$ $+/-0.03)$, reduced cytochrome $\mathrm{c}(\mathrm{n}=6)$, lactate and pyruvate production rates $(\mathrm{n}=2)$ and [lactate]/[pyruvate] are shown. C. Recovery of OCR after hypoxia relative to OCR pre-hypoxia values in retina and islets ( $t$ test result: $p=0.035$, for retina, $n=6$, and for islets $n=3$ ). 
bioRxiv preprint doi: https://doi.org/10.1101/2021.03.07.434330; this version posted March 8, 2021. The copyright holder for this preprint (which was not certified by peer review) is the author/funder, who has granted bioRxiv a license to display the preprint in perpetuity. It is made available under aCC-BY 4.0 International license.

Dissolved Gases and Electron Transport

Fig. 5. Effect of $\mathrm{H}_{2} \mathrm{~S}$ on ISR by islets. A. Rat islets (50/channel) were perifused (flow rate $=200$ $\mathrm{uL} / \mathrm{min}$ ), and ISR was measured in response to glucose and exposure to dissolved $\mathrm{H}_{2} \mathrm{~S}$ in the concentrations shown (data is average $+/-\mathrm{SE}, \mathrm{n}=3\left(\mathrm{H}_{2} \mathrm{~S}\right), \mathrm{n}=2\left(\right.$ no $\left.\mathrm{H}_{2} \mathrm{~S}\right), \mathrm{p}<0.05$ as indicated). B. ISR was measured at the indicated concentrations of dissolved $\mathrm{H}_{2} \mathrm{~S}$. Each curve is a single experiment. C. Data from perifusions as shown in B were plotted as a function of the ISR at the peak between 1 and 1.5 hours, and the average ISR between 3 and 4 hours.

Fig. 6. Flow culture system/assessment system for studying effects of dissolved gases on tissue or cells. One channel/perifusion chamber is shown, but the actual system can accommodate up to 8. A. The perifusion system consisted of an 8-channel peristaltic pump (MiniPuls 2, Gilson, Middleton, WI) connected to a 6-port valve (Part \# V-451, IDEX Health and Science, Oak Harbor, WA) to produce up to six separate solutions; a media/dissolved gas equilibrium system in which media flowed through thinwalled Silastic ${ }^{\mathrm{TM}}$ tubing (0.062 in ID x 0.095 in OD; Dow Corning Corp., Midland, MI) for a residence time of 5 minutes (typically $0.2-0.5 \mathrm{~m}$ depending on the flow rate) loosely coiled in a glass jar that contained various $\mathrm{O}_{2}, 5 \% \mathrm{CO}_{2} /$ balance $\mathrm{N}_{2}$; bubble trap comprised of a Simax Borosilicate glass tube (Mountain Glass, Asheville, NC, 2" long and $4.2 \mathrm{~mm}$ ID) filled with glass wool; a Simax Borosilicate glass perifusion chamber (3" long and $4.2 \mathrm{~mm}$ ID) immersed in a $37^{\circ} \mathrm{C}$ water bath; Lifetime detection spectrometers (Tau Theta, Boulder CO), a tungsten-halogen light source/USB2000 spectrophotometer (Ocean Optics OH); and a Foxy 200 fraction collector (Isco, Inc., Lincoln, NE). B. A blow up of individual parts shown in A. 1.) the glass perifusion chamber containing culture beads, porous frits (Interstate Specialty Products, Suton, MA, Cat no. POR 4894, cut to $4.2 \mathrm{~mm}$ diameter and 0.25 in long) to support the tissue and disperse the flow, and coated with $\mathrm{O}_{2}$-sensitive dye on the interior above and below where the tissue resides; 2) gas equilibration chamber, where media flows through gas permeable Silastic ${ }^{\mathrm{TM}}$ tubing and equilibrates with the gasses filling the headspace; 3) bubble traps. C. Incorporation of a permeation tube (VICI Metronics, Poulsbo, WA) that releases $\mathrm{H}_{2} \mathrm{~S}$ at specified rates into the media/dissolved gas equilibration system during which time the ports for the inflow and outflow of carrier gas $\left(\mathrm{O}_{2}, \mathrm{C} \mathrm{O}_{2}\right.$ and $\left.\mathrm{N}_{2}\right)$ are closed. The resulting accumulation of $\mathrm{H}_{2} \mathrm{~S}$ in the artificial lung yields linearly increasing concentrations of dissolved $\mathrm{H}_{2} \mathrm{~S}$ in the form of a ramp function as shown.

Fig. 7. Control and measurement of dissolved $\mathbf{O}_{2}$. A. At 20-30 minute intervals, the lung was sequentially filled with $21,15,10,5,3,1$, and $0 \% \mathrm{O}_{2}$. B. The steady state lifetime measurements were non-linear and conformed to a Stern-Volmer equation. Where the $\mathrm{pO}_{2}$ is partial pressure of oxygen molecules (oxygen tension), $\tau_{0}$ is lifetime of the dye without quencher such as oxygen molecule, $\mathrm{k}_{1}$ is $1 / \tau_{0}$ and $\mathrm{k}_{\mathrm{q}}$ is a bimolecular quenching constant of the dye by oxygen molecules. The $\mathrm{k}_{1}$ and $\mathrm{k}_{\mathrm{q}}$ were 15519 $\mathrm{sec}^{-1}$ and $1612.2 \mathrm{mmHg}^{-1} \mathrm{sec}^{-1}$, respectively. C. Test of precision at normal $\mathrm{O}_{2} . \mathrm{O}_{2}(142 \mathrm{~mm} \mathrm{Hg})$ in the lung was changed first to $106.5 \mathrm{~mm} \mathrm{Hg}$ and back to 142 (levels of change that were typical what was observed in our studies). By mixing 21 and 15\% tanks at known flow rates, $\mathrm{O}_{2}$ was then decreased by 3 $\mathrm{mm} \mathrm{Hg}$ and then subsequently by $8 \mathrm{~mm} \mathrm{Hg}$. D. Test of precision and $\mathrm{S} / \mathrm{N}$ of low $\mathrm{O}_{2} \cdot \mathrm{O}_{2}(21 \mathrm{~mm} \mathrm{Hg})$ in the lung was changed first to $7 \mathrm{~mm} \mathrm{Hg}\left(1 \% \mathrm{O}_{2}\right)$ and back to 21 . By mixing 3 and $1 \%$ tanks at known flow rates, $\mathrm{O}_{2}$ was decreased by $1.9 \mathrm{~mm} \mathrm{Hg}$. $\mathrm{S} / \mathrm{N}$ was for the $14 \mathrm{mmHg}$ and the $1.9 \mathrm{~mm} \mathrm{Hg}$ changes was $>80$ and $>10$ respectively.

Fig. 8. Determination of transfer function from inflow and outflow for convolution analysis. Measurement of inflow and outflow $\mathrm{O}_{2}$ tensions in response to a change from 21 to $1 \%$ with no live tissue in the system. Deconvolution was carried out to generate the transfer function of the system shown on the bottom graph. 
GLUCOSE

Fig 1.

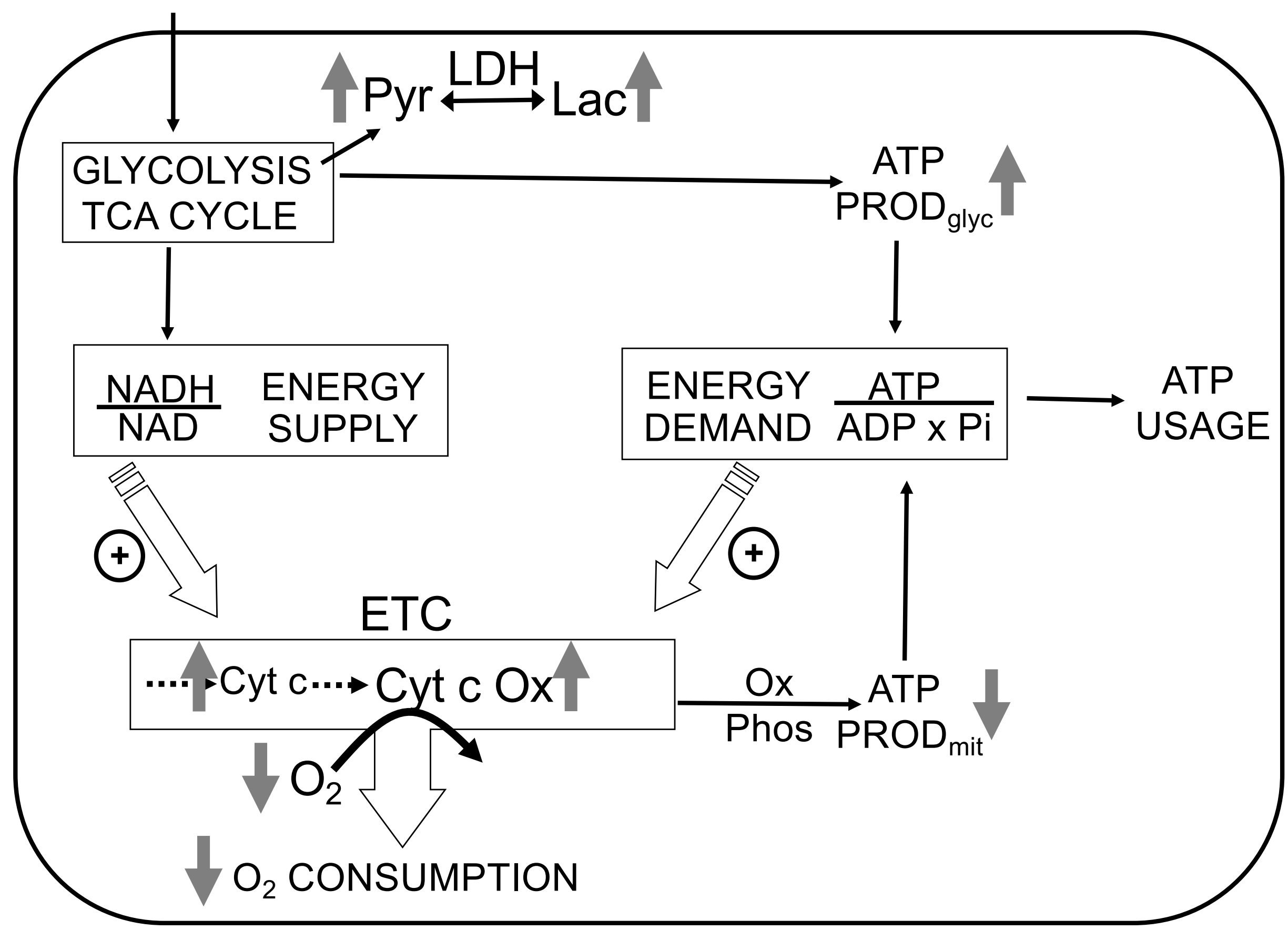


Fig. 2A.

A

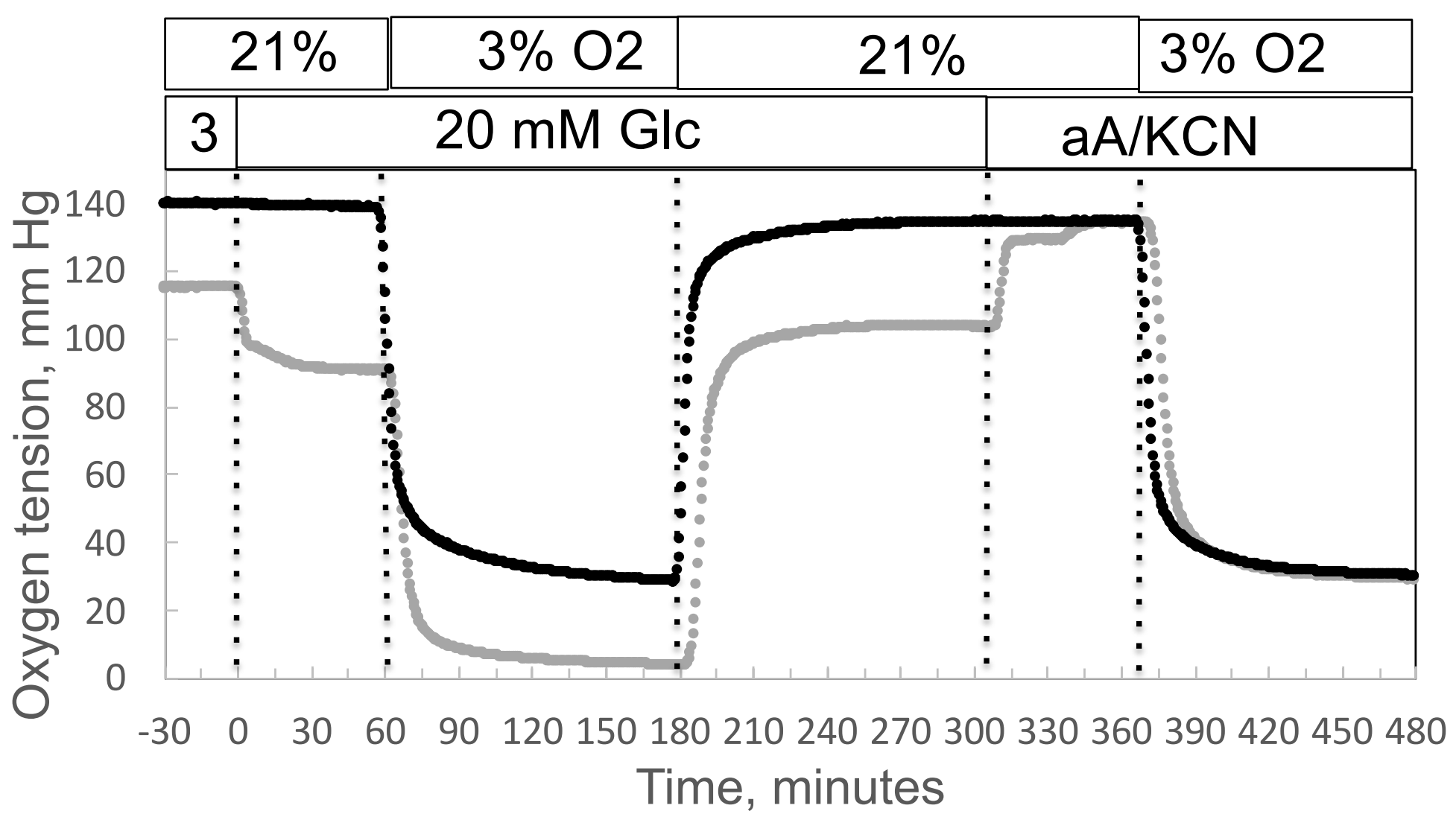


Fig. 2B.
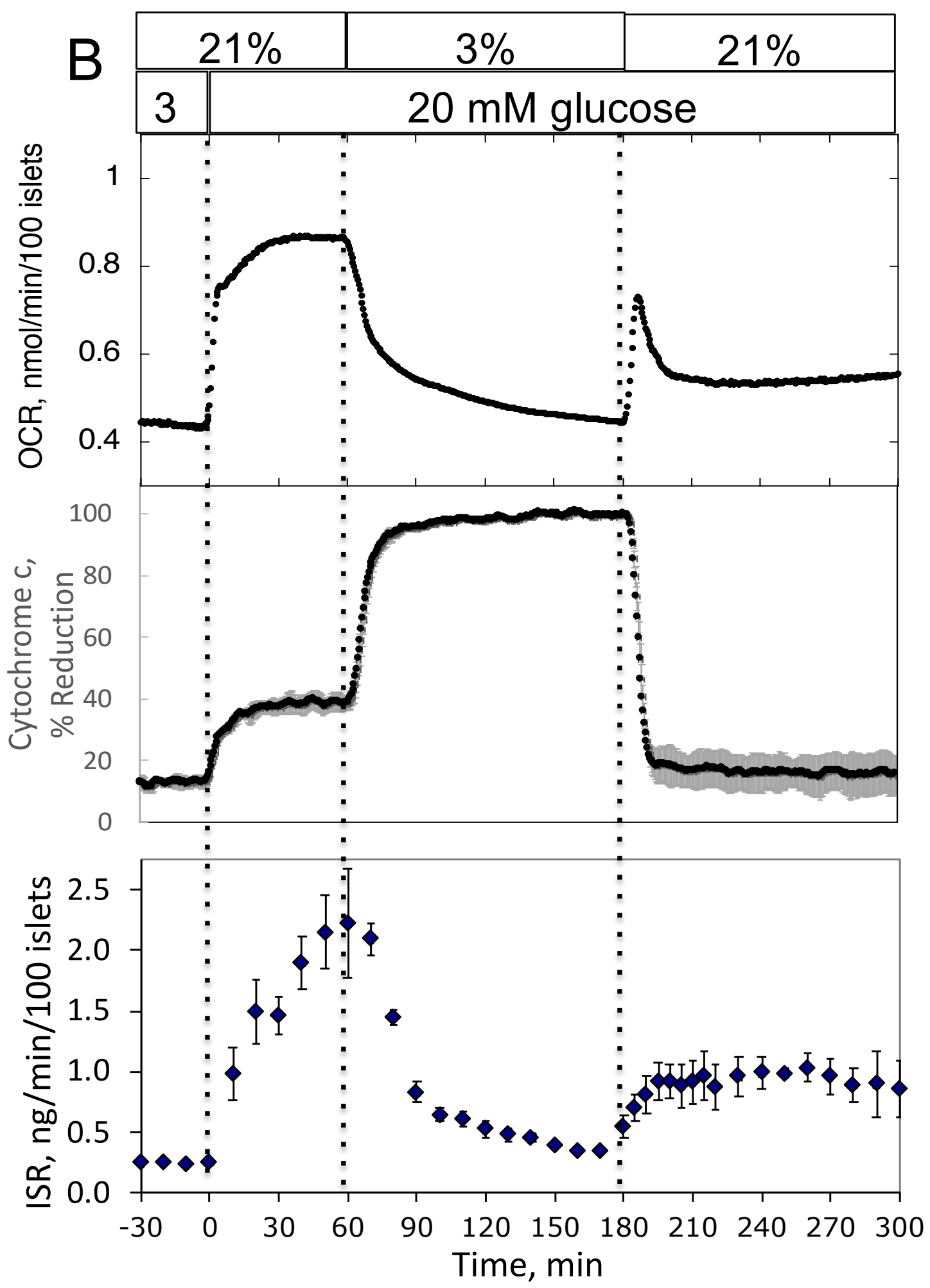
Fig. 2C.

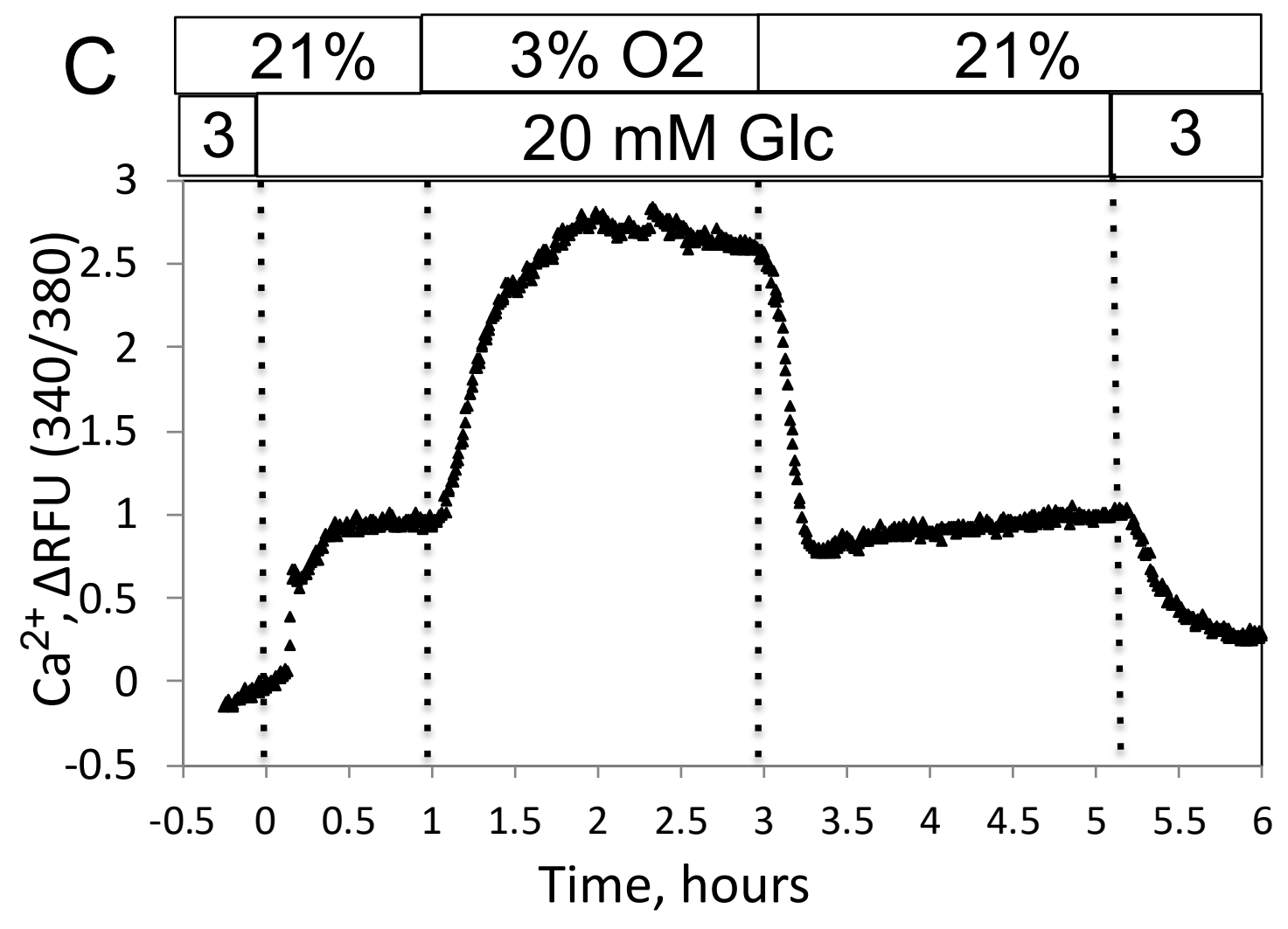


bioRxiv preprint doi: https://doi.org/10.1101/2021.03.07.434330; this version posted March 8, 2021. The copyright holder for this preprint (which was not certified by peer review) is the author/funder, who has granted bioRxiv a license to display the preprint in perpetuity. It is made Fig 3 A. available under aCC-BY 4.0 International license.

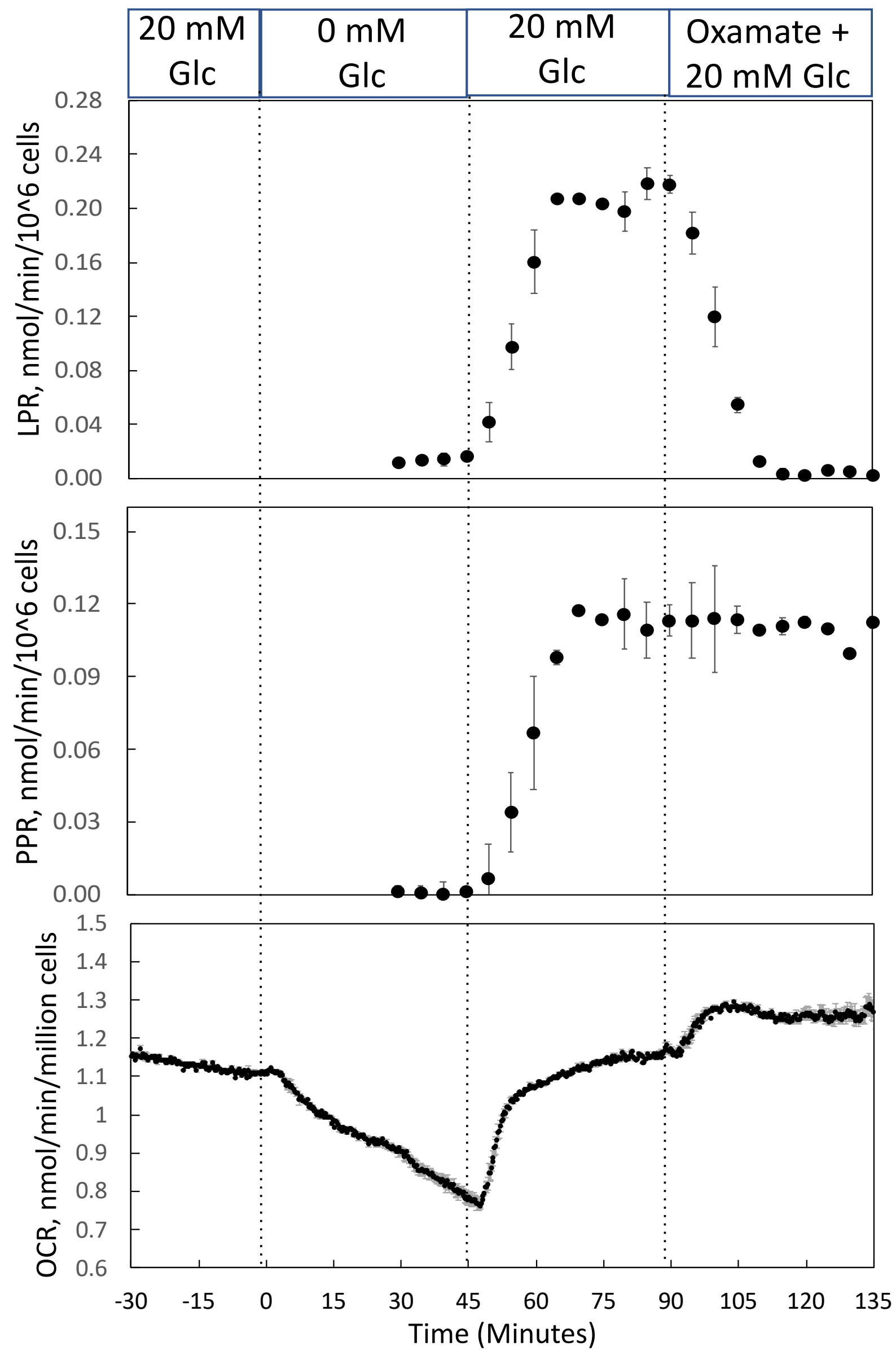


bioRxiv preprint doi: https://doi.org/10.1101/2021.03.07.434330; this version posted March 8, 2021. The copyright holder for this preprint (which was not certified by peer review) is the author/funder, who has granted bioRxiv a license to display the preprint in perpetuity. It is made available under aCC-BY 4.0 International license.

Fig. 3B

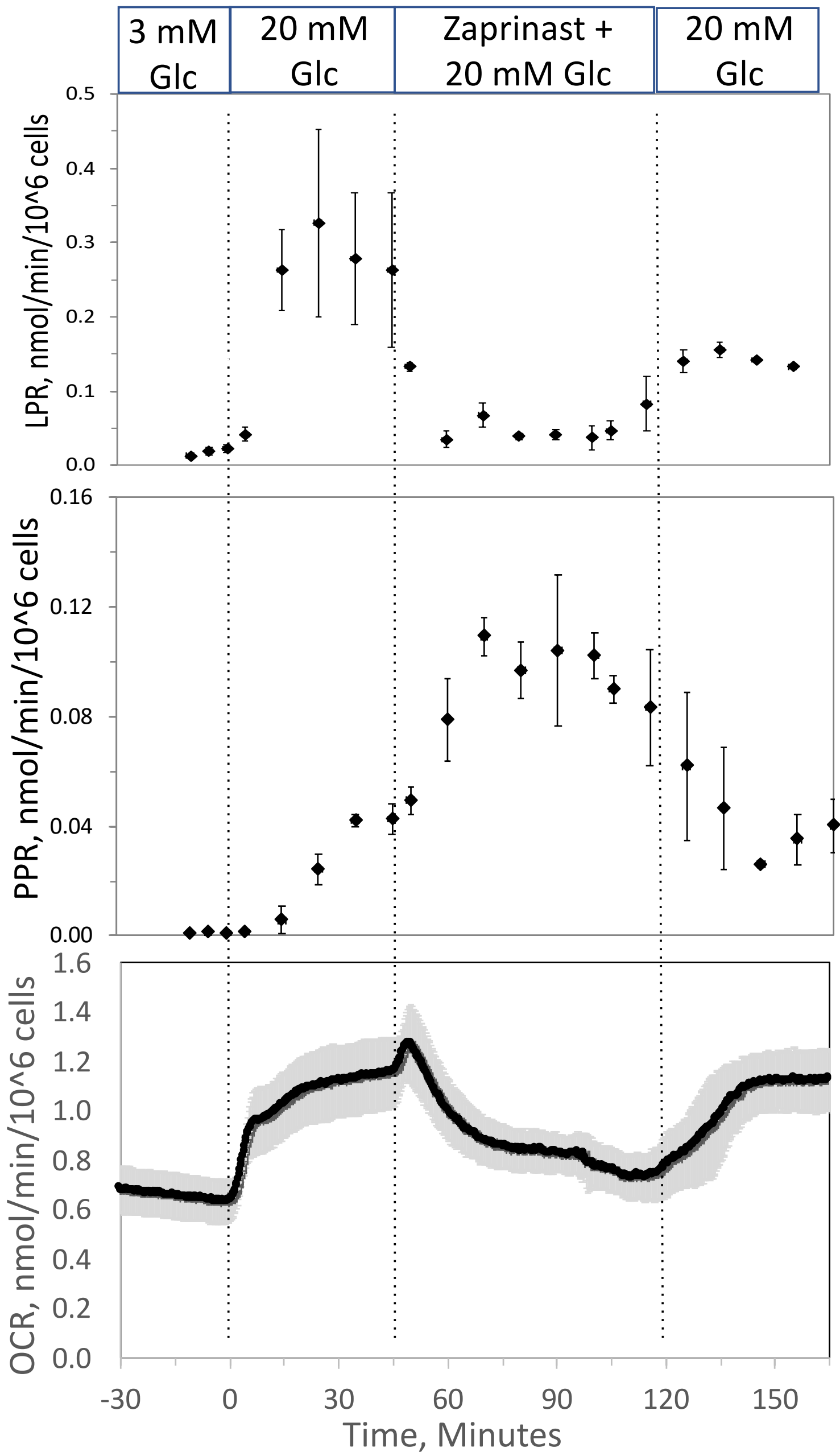


bioRxiv preprint doi: https://doi.org/10.1101/2021.03.07.434330; this version posted March 8, 2021. The copyright holder for this preprint (which was not certified by peer review) is the author/funder, who has granted bioRxiv a license to display the preprint in perpetuity. It is made available under aCC-BY 4.0 International license.

Fig. 4A.

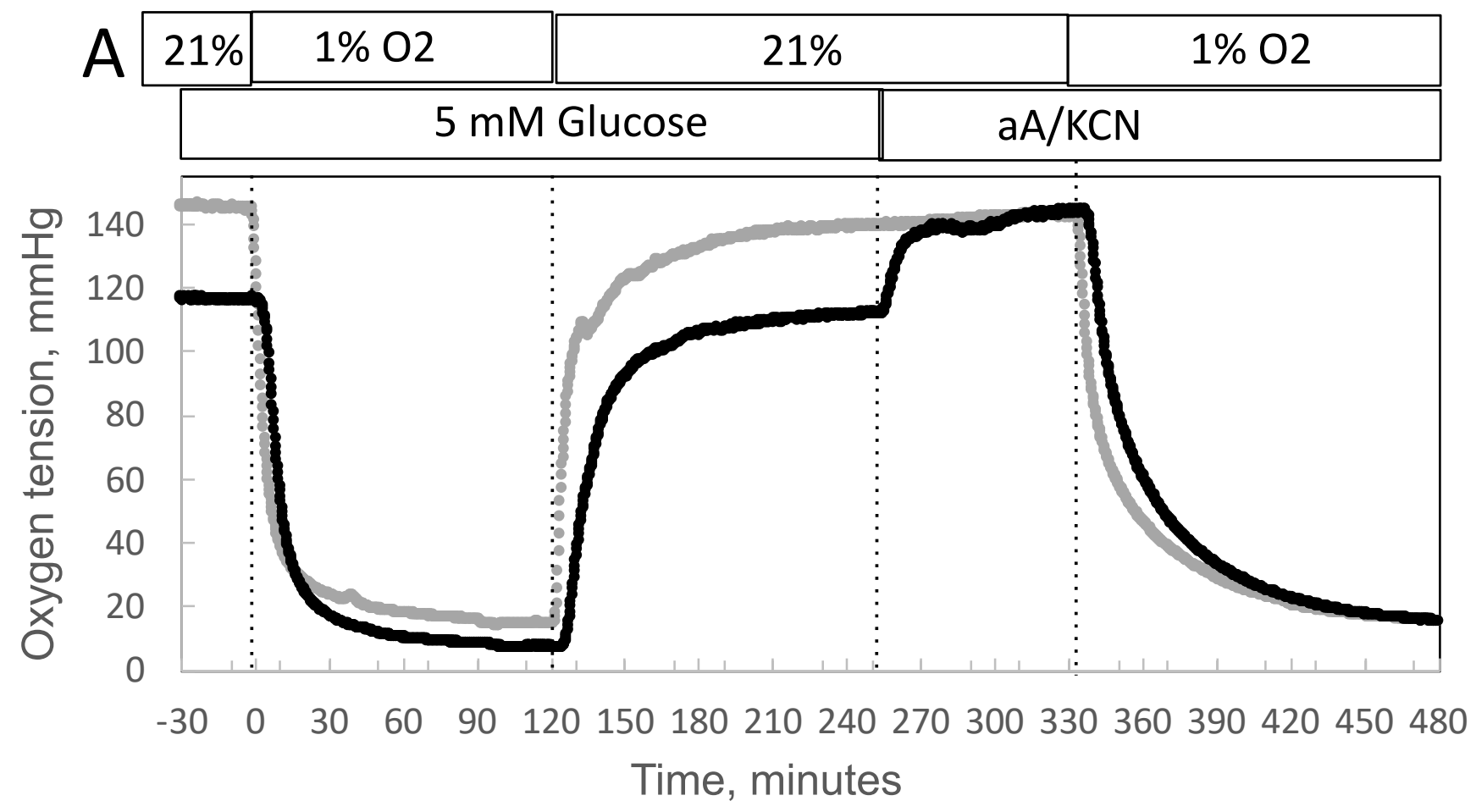


bioRxiv preprint doi: https://doi.org/10.1101/2021.03.07.434330; this version posted March 8, 2021. The copyright holder for this preprint (which was not certified by peer review) is the guthorffunder, who has granted bioRxiv a license to display the preprint in perpetgity. It is made Fig. 4B.
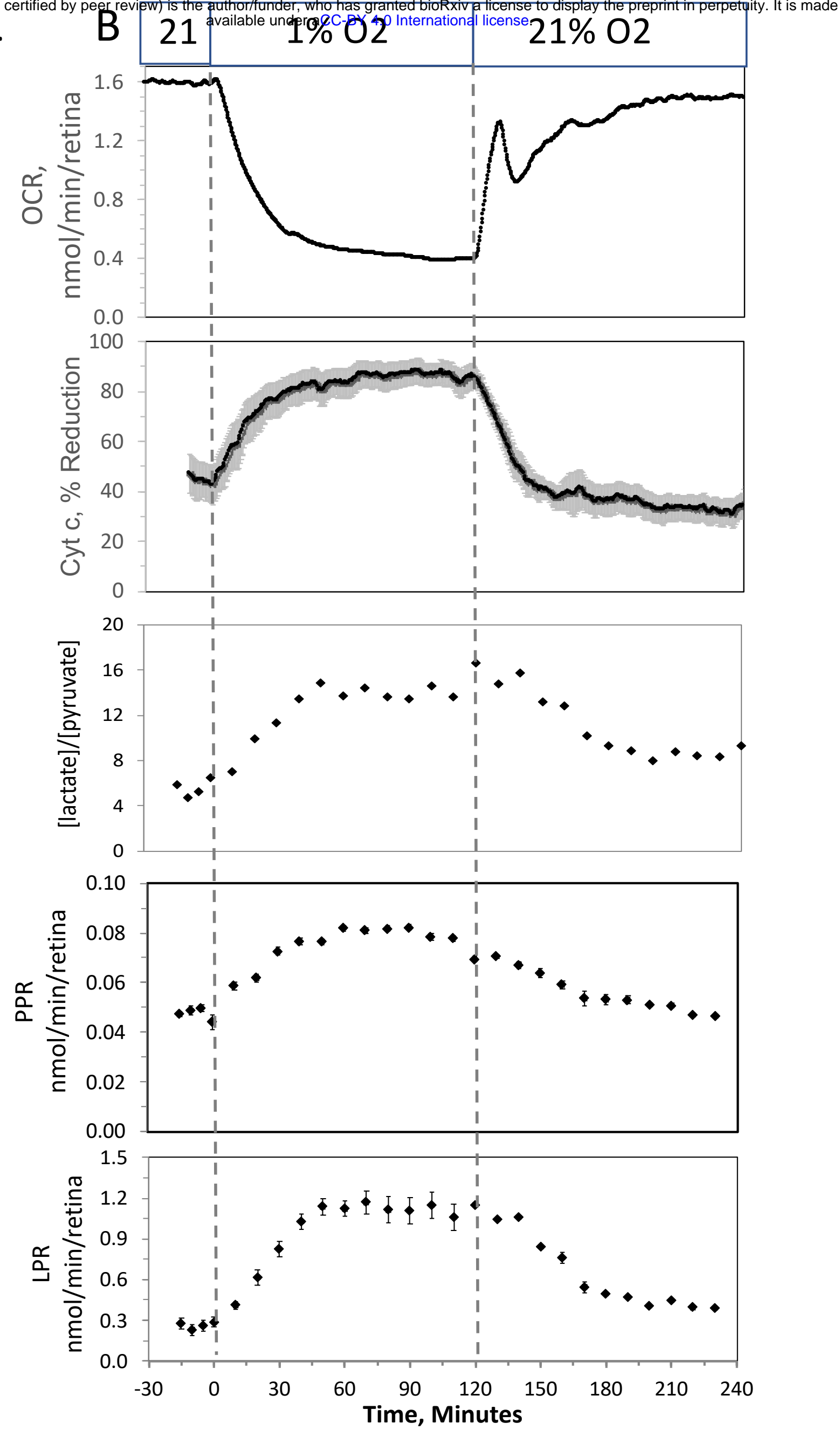
bioRxiv preprint doi: https://doi.org/10.1101/2021.03.07.434330; this version posted March 8, 2021. The copyright holder for this preprin (which was not certified by peer review) is the author/funder, who has granted bioRxiv a license to display the preprint in perpetuity. It is made available under aCC-BY 4.0 International license.

Fig. 4C.

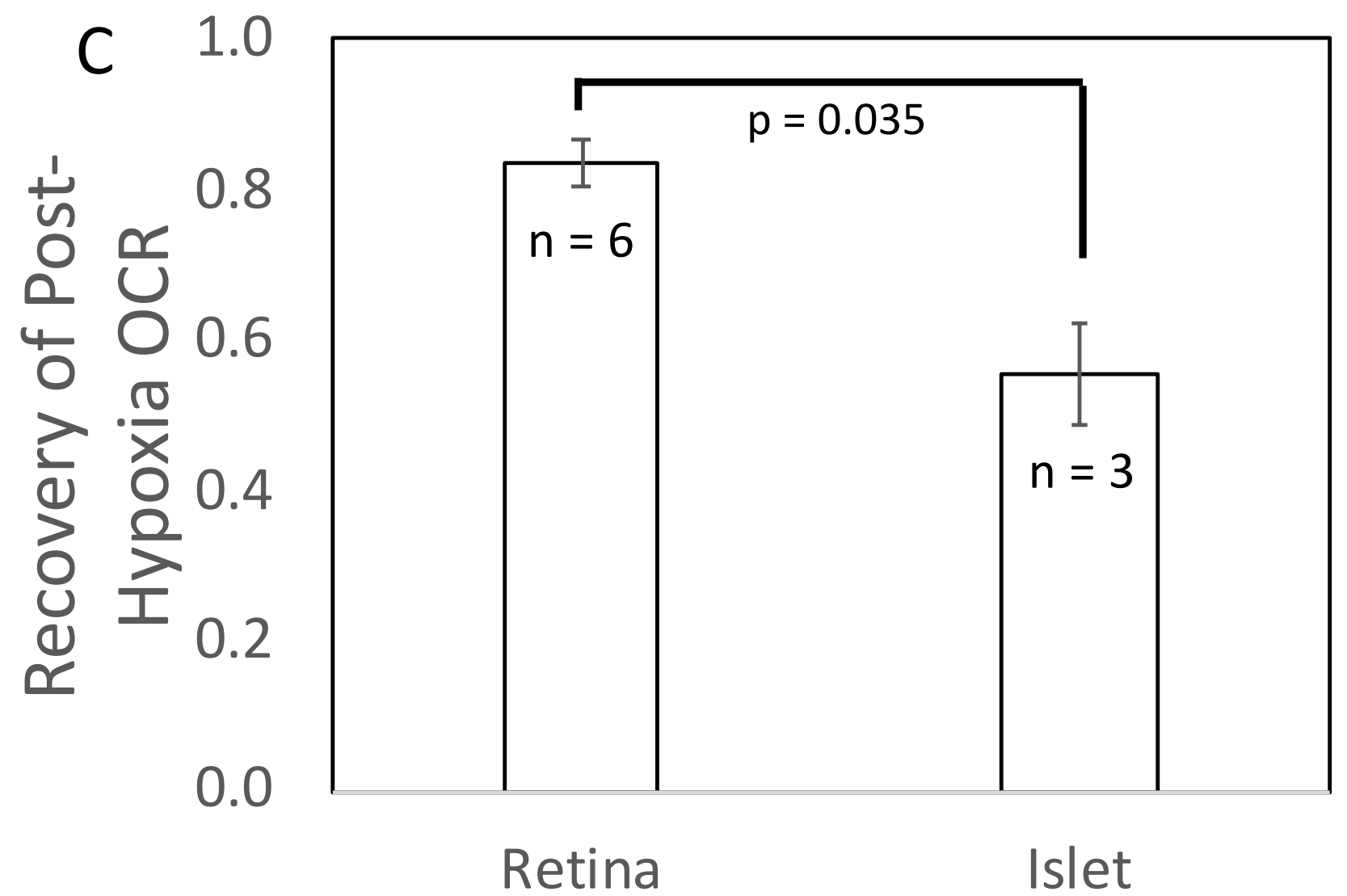


bioRxiv preprint doi: https://doi.org/10.1101/2021.03 07.434330; this version posted March 8, 2021. The copyright holder for this preprint (which was not certified by peer review) is the author/funder, who has granted bioRxiv a license to display the preprint in perpetuity. It is made Fig. 5A. available under aCC-BY 4.0 International license.

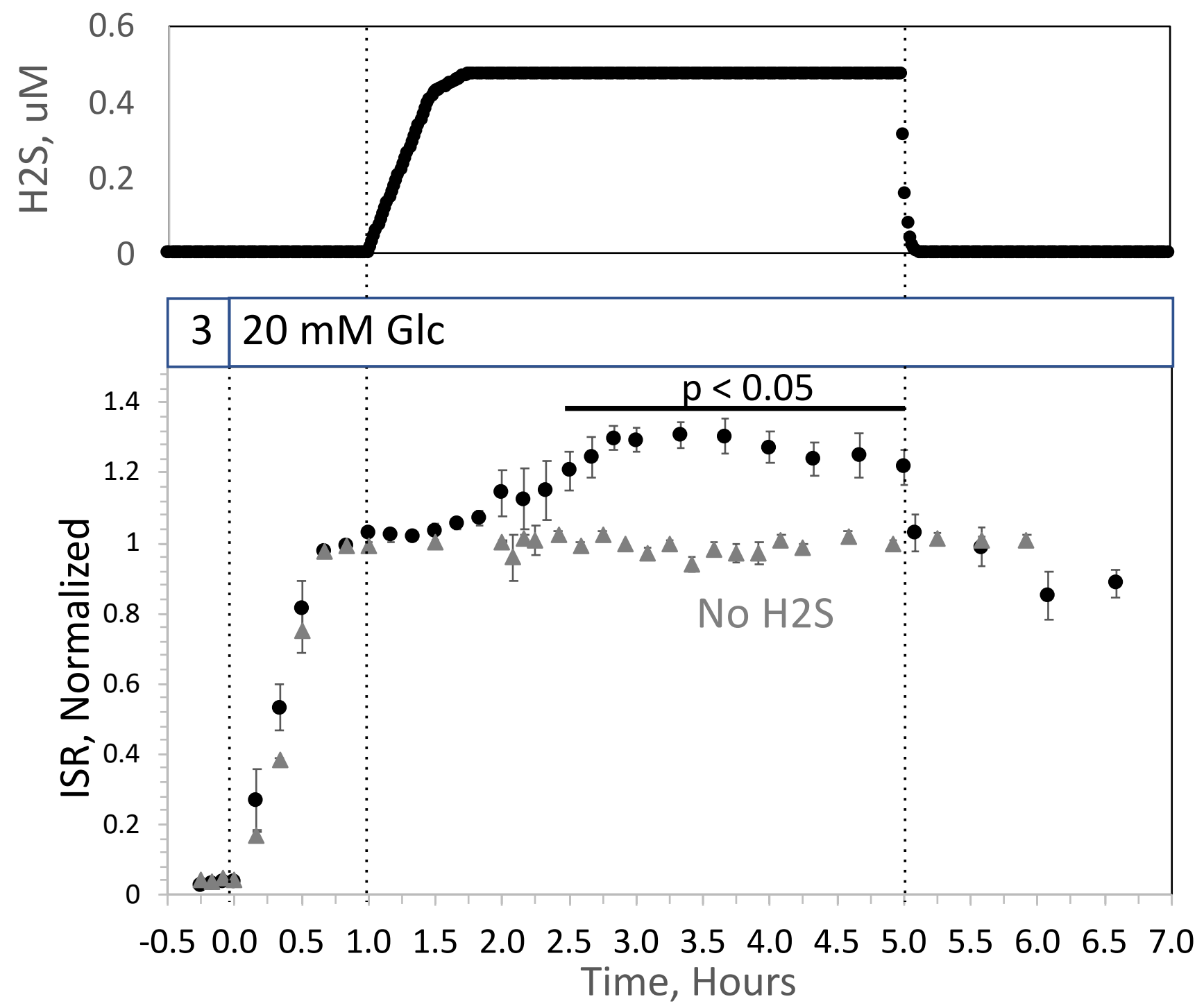


bioRxiv preprint doi: https://doi.org/10.1101/2021.03.07.434330; this version posted March 8, 2021. The copyright holder for this preprint (which was not certified by peer review) is the author/funder, who has granted bioRxiv a license to display the preprint in perpetuity. It is made Fig. 5B.

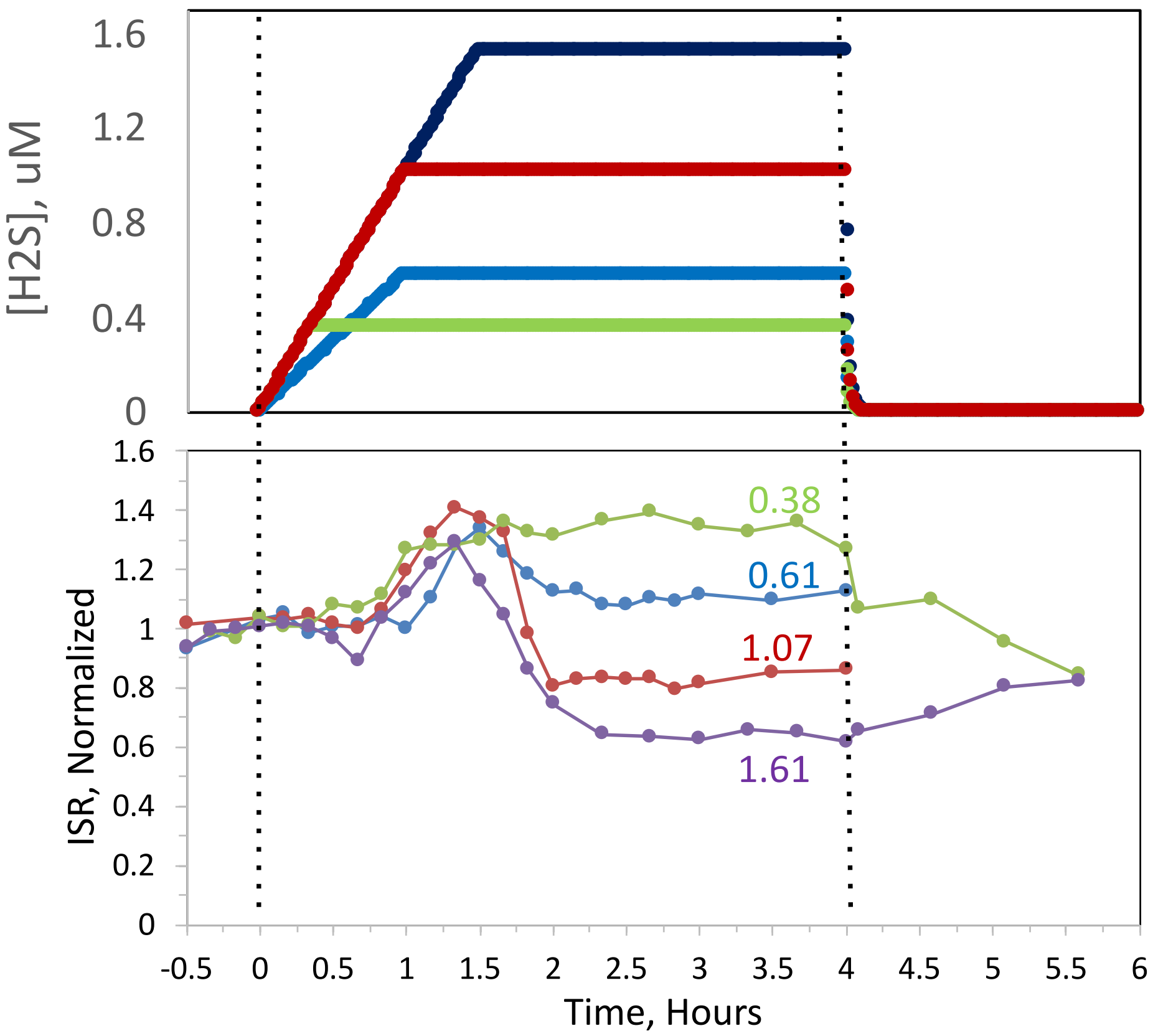


bioRxiv preprint doi: https://doi.org/10.1101/2021.03.07.434330; this version posted March 8, 2021. The copyright holder for this preprint (which was not certified by peer review) is the author/funder, who has granted bioRxiv a license to display the preprint in perpetuity. It is made available under aCC-BY 4.0 International license.

Fig. 5C.

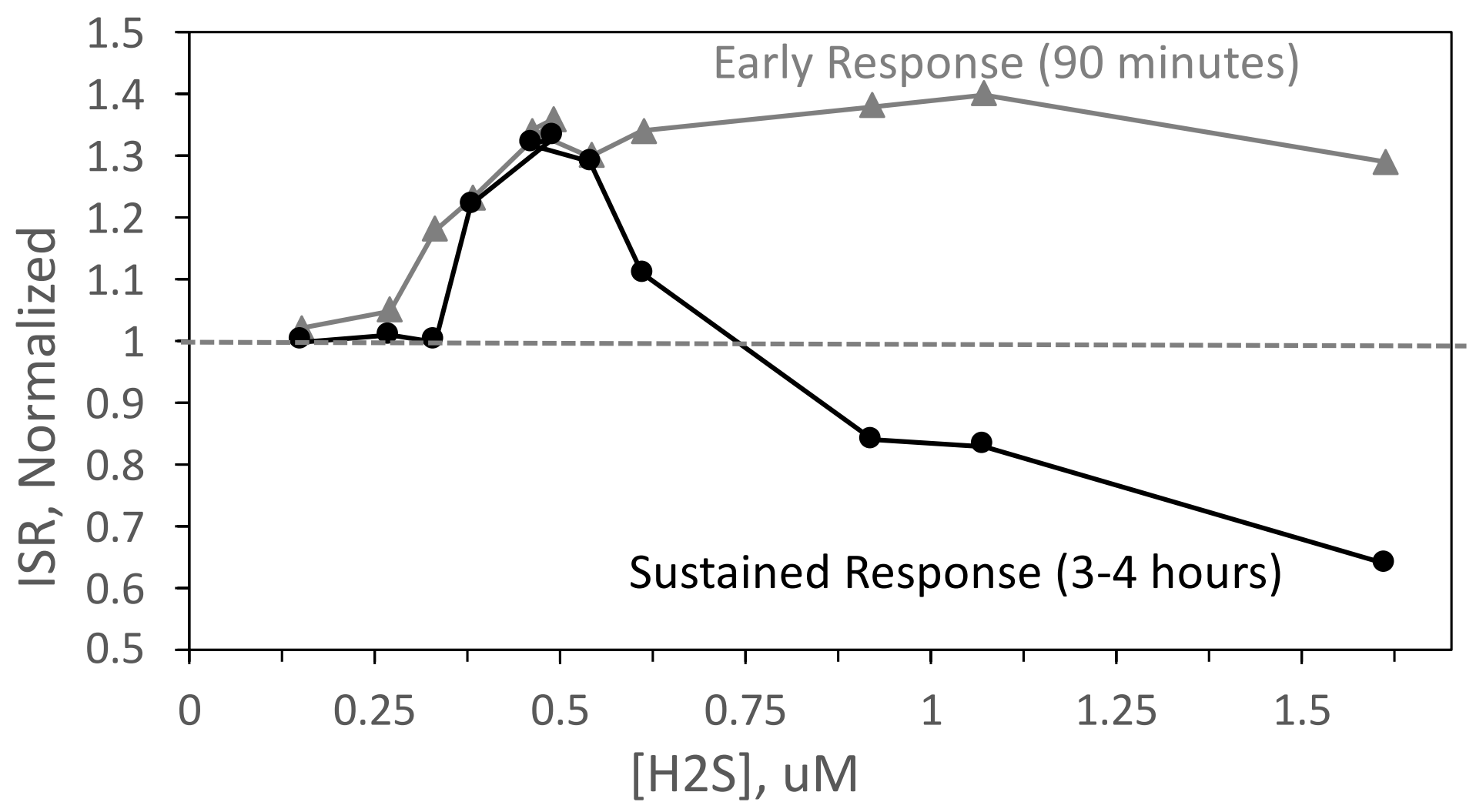


Fig. 6A-B.
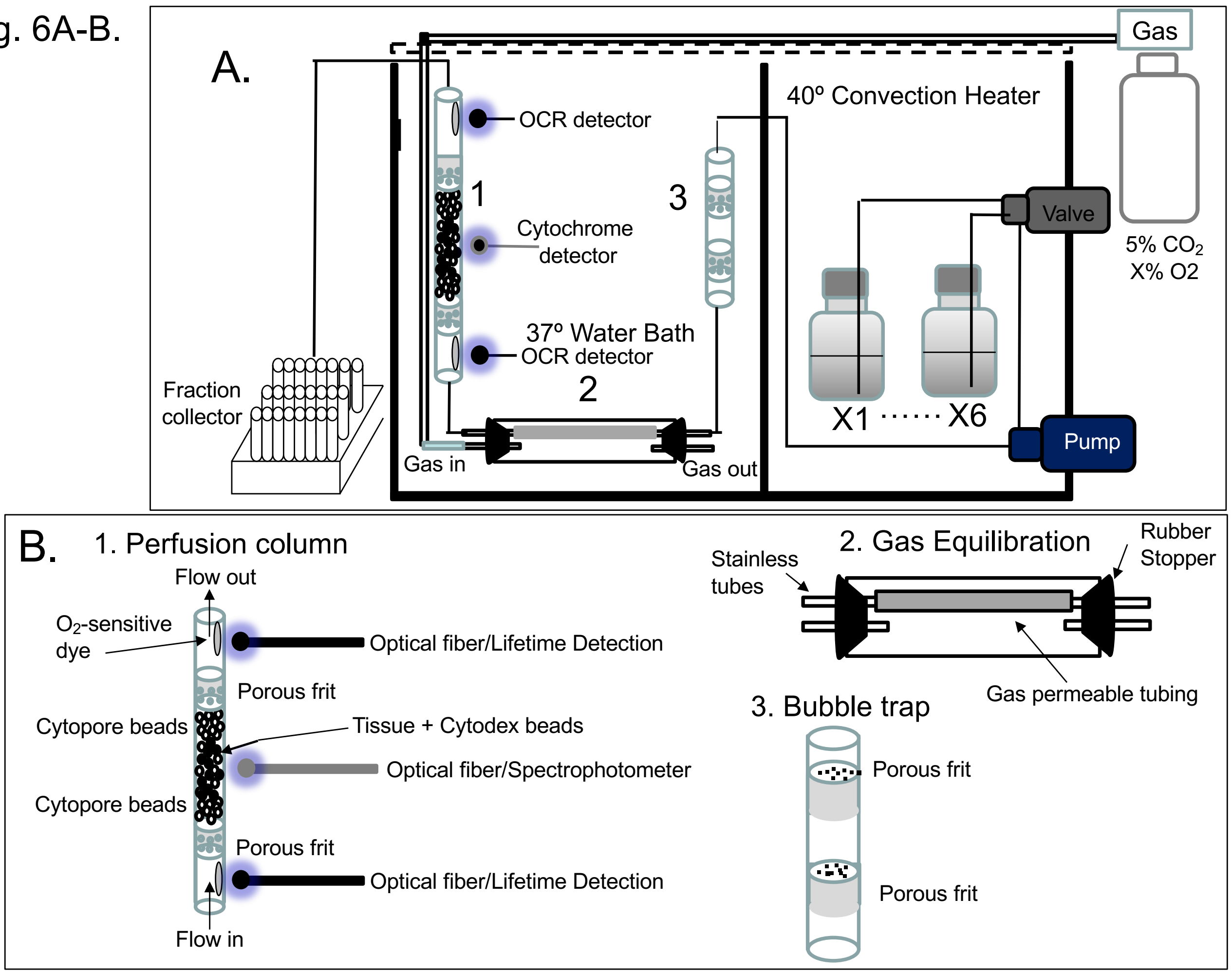
Fig. 6C.

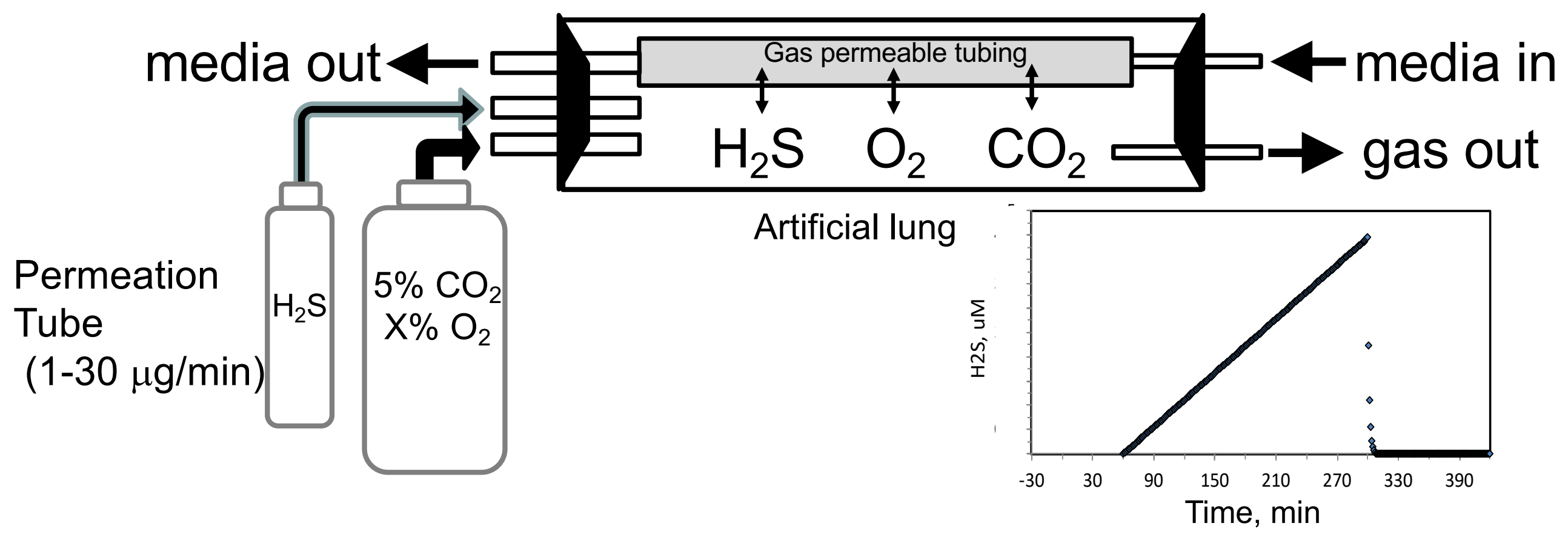




\section{Fig. 7A-B}
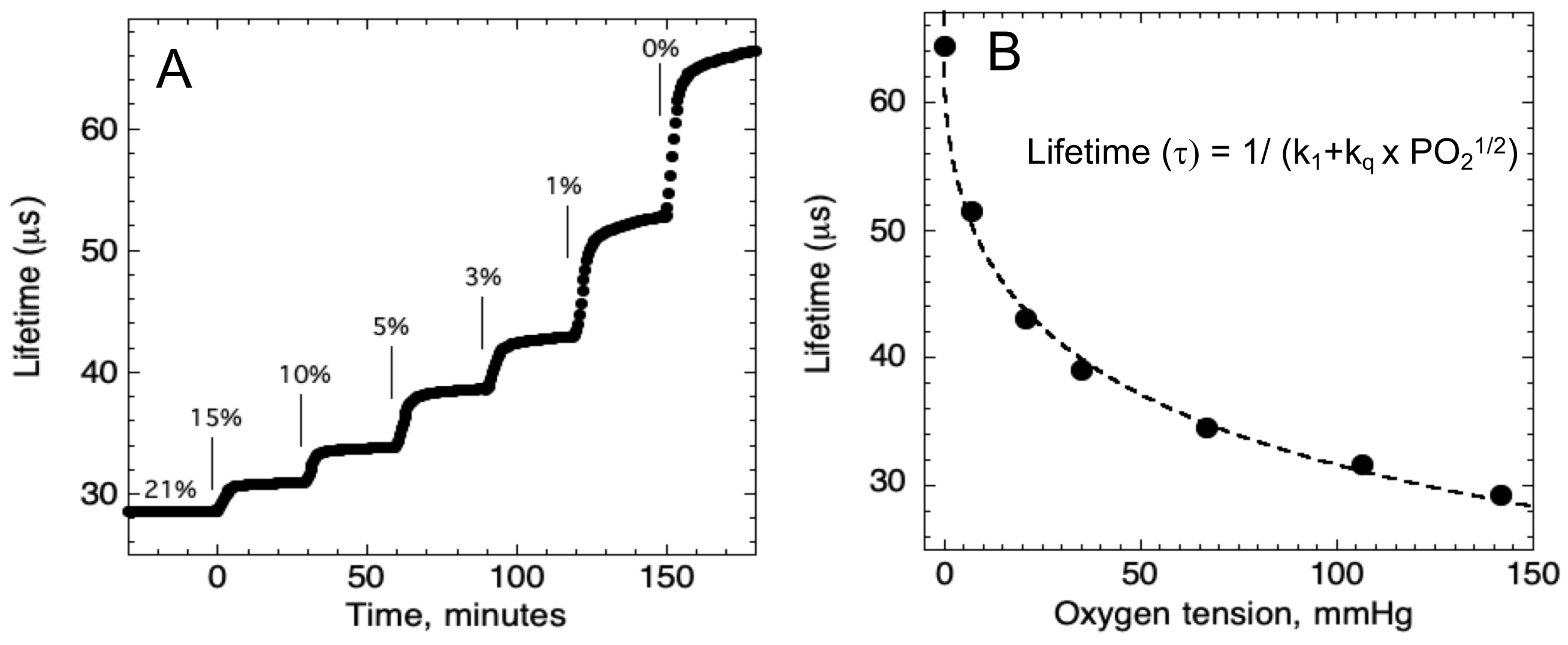


\section{Fig. 7C-D.}
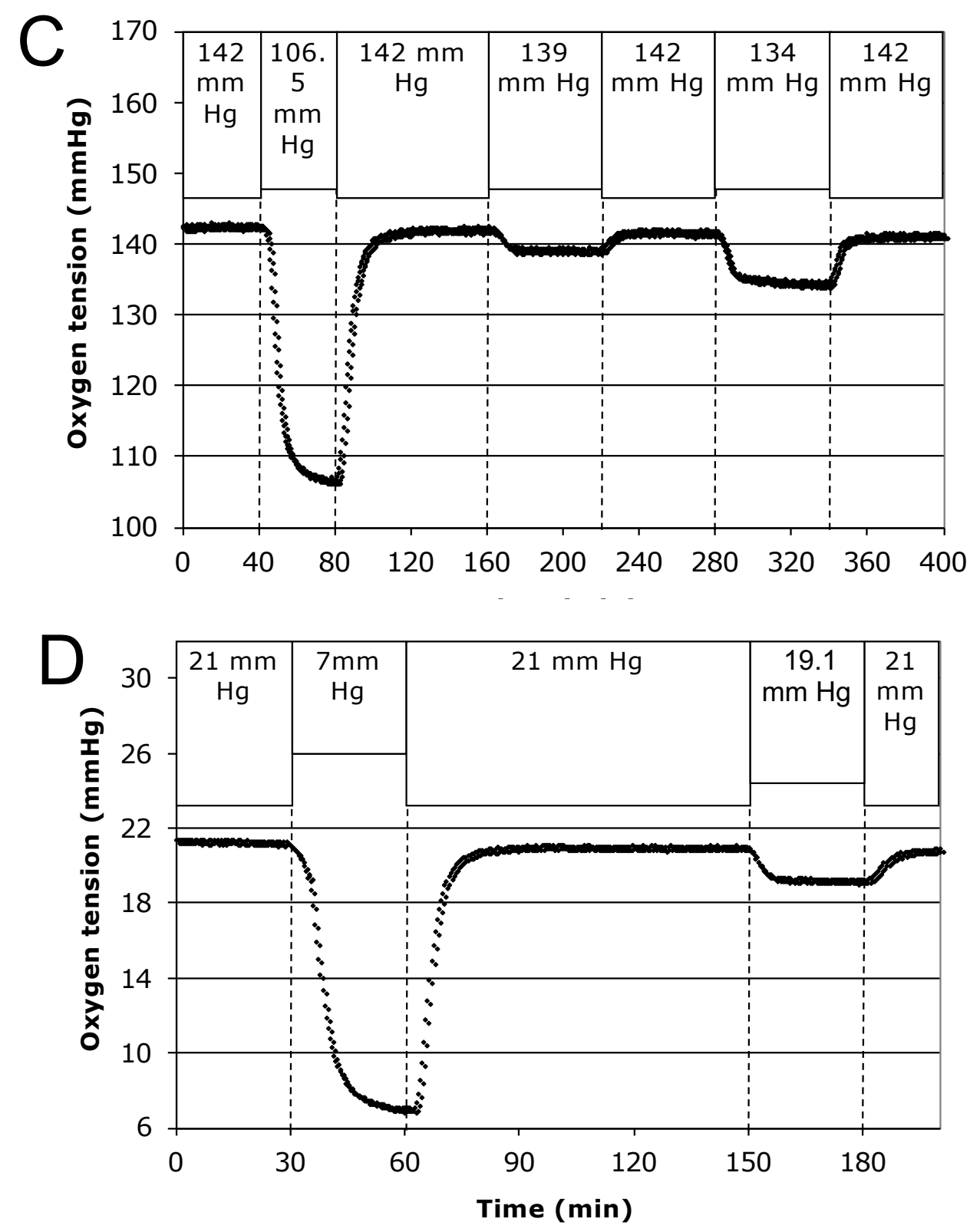
Fig. 8.

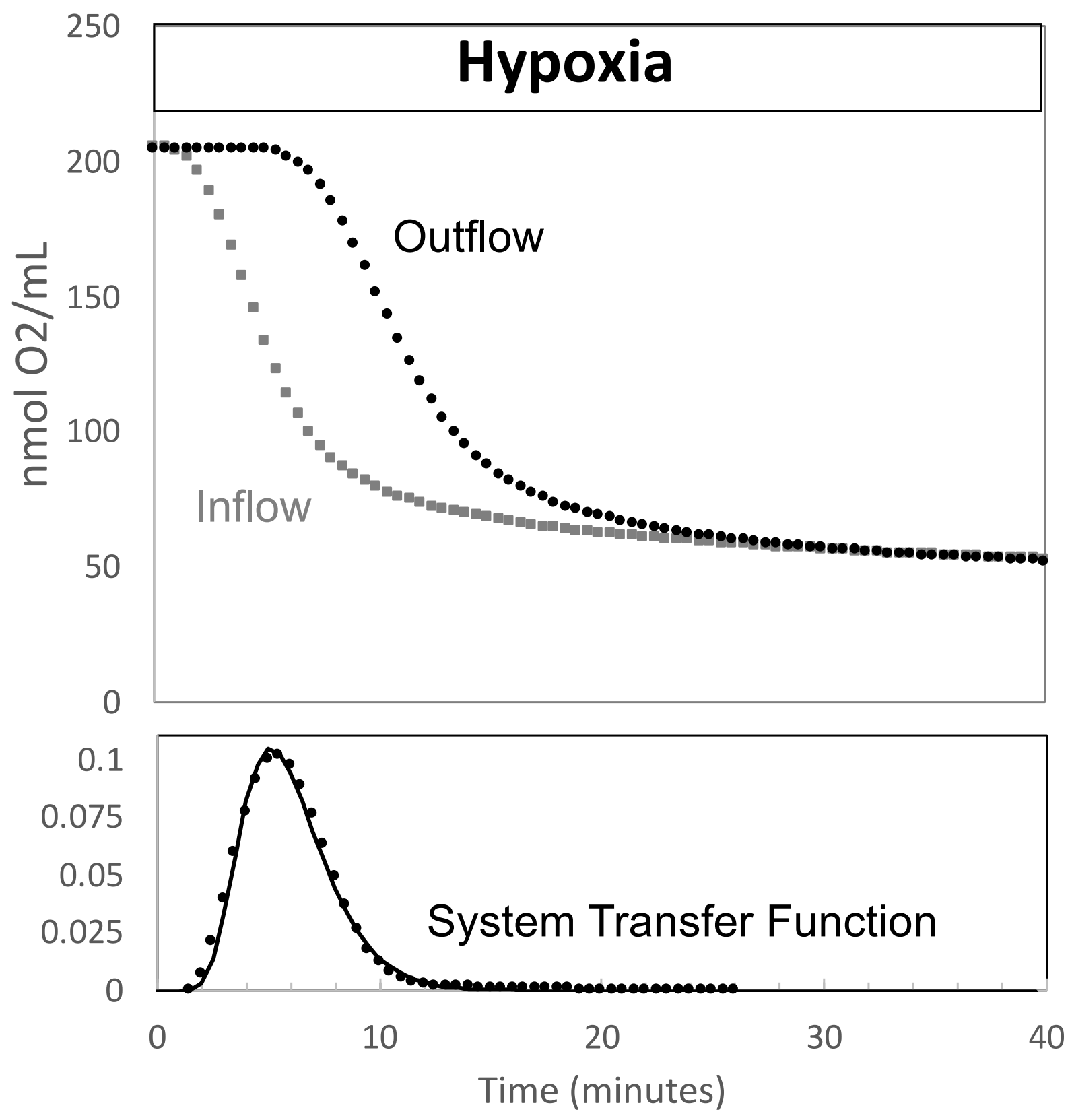




\section{APPENDIX}

\section{Fluidics System for Resolving Concentration-Dependent Effects of Dissolved} Gases on Tissue Metabolism

\section{Varun Kamat ${ }^{1}$, Brian M. Robbings ${ }^{1,3}$, Seung-Ryoung Jung ${ }^{1}$, John Kelly², James B. Hurley ${ }^{3}$, Kenneth P. Bube ${ }^{4}$ and Ian R. Sweet ${ }^{1}$}

\section{From}

${ }^{1}$ University of Washington Medicine Diabetes Institute, University of Washington, Seattle, WA, 98109.

${ }^{2}$ VICI Metronics, 26295 Twelve Trees, Poulsbo, Washington 98370

${ }^{3}$ Department of Biochemistry, University of Washington, Seattle, WA, 98109

${ }^{4}$ Department of Mathematics, University of Washington, Seattle, WA, 98195

Running Title: Dissolved Gases and Electron Transport.

Address correspondence to: Ian R Sweet, Box \# 358062, F763, UW Medicine Diabetes Institute, University of Washington, 750 Republican St Building F, Seattle, WA 98109-4725

Tel. (206) 685-4775; Fax: (206) 543-3169; E-mail: isweet@uw.edu

Varun Kamat and Brian Robbings are co-first authors. 
bioRxiv preprint doi: https://doi.org/10.1101/2021.03.07.434330; this version posted March 8, 2021. The copyright holder for this preprint

(which was not certified by peer review) is the author/funder, who has granted bioRxiv a license to display the preprint in perpetuity. It is made available under aCC-BY 4.0 International license.

Dissolved Gases and Electron Transport

\section{APPENDIX METHODS}

Chemicals. Antimycin A, glucose, potassium cyanide (KCN) and succinate were purchased from Sigma-Aldrich.

Preparation of Liver slices. Liver pieces from rats were prepared as previously described ${ }^{1}$. Ten pieces (about $0.25 \times 1 \mathrm{~mm}$ (mass= 2.5-3.5 mg per piece)) were loaded into each tissue perifusion chamber without succinate, or four pieces for chambers with succinate for each analysis. After the end of each experiment, liver samples were weighed, and OCR measurements were normalized to this mass. Liver pieces had no Cytodex bead layering, but otherwise had the same loading procedure as described for retina chambers, the same supplemented KRB was continuously flowed at a rate of about $95 \mathrm{uL} / \mathrm{min}$ after initially loading the tissue at $30 \mathrm{uL} / \mathrm{min}$. Procedures were approved by the University of Washington Institutional Animal Care and Use Committee.

\section{APPENDIX RESULTS}

Effect of NaHS on glucose-stimulated ISR by isolated rat islets. To test the ability of NaHS to emulate the of $\mathrm{H}_{2} \mathrm{~S}$, islets in the flow culture system at incrementally increasing concentrations of $\mathrm{NaHS}$. No effect was seen at concentration below $10 \mu \mathrm{M}$ (APPENDIX Fig. 1A), a range that $\mathrm{H}_{2} \mathrm{~S}$ had both stimulatory and inhibitory effects on ISR. At higher concentrations, NaHS inhibited ISR where the IC50 was about $30 \mu \mathrm{M}$ and each concentration change reached a new steady state within 10-15 minutes.

Effect of $\mathrm{H}_{2} \mathrm{~S}$ on liver in the presence and absence of a mitochondrial fuel (succinate). To test the ability of our system to measure the effects of $\mathrm{H}_{2} \mathrm{~S}$, rat liver pieces were placed into the perfusion chambers and exposed to steadily increasing concentrations of dissolved $\mathrm{H}_{2} \mathrm{~S}$. The first effects observed in response to changes in $\mathrm{H}_{2} \mathrm{~S}$ were the increased production rates of lactate and pyruvate (APPENDIX Fig. 2A). About 30 minutes following the start of the ramp increase in $\mathrm{H}_{2} \mathrm{~S}$, OCR, reduced cytochrome $\mathrm{c}$ and cytochrome $\mathrm{c}$ oxidase all decreased very precipitously for about 20 minutes, followed by a sudden increase until $\mathrm{H}_{2} \mathrm{~S}$ was purged from the system (APPENDIX Fig. 2A). During the post- $\mathrm{H}_{2} \mathrm{~S}$ phase, all three of these parameters remained low. After a second introduction of $\mathrm{H}_{2} \mathrm{~S}$, OCR, reduced cytochrome $\mathrm{c}$ and cytochrome c oxidase all increased about 30 minutes following the start of the ramp. These waveforms suggest multiple points of action by $\mathrm{H}_{2} \mathrm{~S}$ and is consistent with a scenario where $\mathrm{H}_{2} \mathrm{~S}$ can irreversibly inhibit complex 1 or a step upstream from complex 1 (consistent with decreased cytochromes and OCR), but also can supply electrons directly to cytochrome $\mathrm{c}$ when the level of $\mathrm{H}_{2} \mathrm{~S}$ reaches higher concentrations.

In the presence of a fuel that enters at complex 2 (succinate), OCR, reduced cytochrome $\mathrm{c}$ and reduced cytochrome c oxidase all increased (APPENDIX Fig. 2B). Under these conditions, $\mathrm{H}_{2} \mathrm{~S}$ decreased OCR and cytochrome c reduction, but increased cytochrome c oxidase reduction, suggesting that $\mathrm{H}_{2} \mathrm{~S}$ was inhibiting both at complex 1 and 4 . In contrast to the experiments done in the absence of succinate, post- $\mathrm{H}_{2} \mathrm{~S}$ metabolism was only slightly different than pre- $\mathrm{H}_{2} \mathrm{~S}$ energy state reflecting the continued supply of electrons to the ETC when complex 1 is still inhibited, while complex 4 inhibition by $\mathrm{H}_{2} \mathrm{~S}$ seemed to be reversible. Following washout of both $\mathrm{H}_{2} \mathrm{~S}$ and succinate, reducing power in the mitochondria fell to near 0 , as would be expected in the absence of complex 1 activity. 
bioRxiv preprint doi: https://doi.org/10.1101/2021.03.07.434330; this version posted March 8, 2021. The copyright holder for this preprint

Dissolved Gases and Electron Transport

\section{APPENDIX DISCUSSION}

Contrasting effect of $\mathrm{H}_{2} \mathrm{~S}$ and NaHS on ISR in the perifusion system. The assumption made in most studies of $\mathrm{H}_{2} \mathrm{~S}$, is that $\mathrm{NaHS}$ or $\mathrm{Na}_{2} \mathrm{~S}$ would rapidly equilibrate with the protonated form of the acid. Whether $\mathrm{NaHS}$ or $\mathrm{H}_{2} \mathrm{~S}$ is added to the solution, the same amount of $\mathrm{H}_{2} \mathrm{~S}$ would be present in solution after a short equilibration time. That $\mathrm{H}_{2} \mathrm{~S}$ stimulated ISR and NaHS did not is therefore hard to explain. One factor to consider is that as the buffer traversed the lung, a significant proportion of the $\mathrm{H}_{2} \mathrm{~S}$ is depleted from the solution as it diffuses into the gas in the head space around the gas-permeable tubing in the gas equilibration system. This would likely be the case in the static conditions that ISR assays are commonly carried out. Nonetheless, one would reason that as NaHS is increased, eventually the dissolved $\mathrm{H}_{2} \mathrm{~S}$ would reach an amount that would stimulate ISR. We have no explanation for why this did not occur, but possibly as $\mathrm{HS}^{-}$gets high enough it can inhibit ISR. So, despite the fact that we cannot explain the lack of stimulatory effect of NaHS, it does support that when investigating the physiological effects of $\mathrm{H}_{2} \mathrm{~S}$, dissolved $\mathrm{H}_{2} \mathrm{~S}$ should be used and calls into question the use of $\mathrm{H}_{2} \mathrm{~S}$ donor molecules.

Control and effects of $\mathrm{H}_{2} \mathrm{~S}$ on liver. To illustrate its use, we exposed liver to $\mathrm{H}_{2} \mathrm{~S}$, an established cell signal with multiple effects and mechanisms of action. Both reported mechanisms of action of $\mathrm{H}_{2} \mathrm{~S}$ in the ETC were observed in this study: inhibition of cytochrome c oxidase ${ }^{2}$ and direct transfer of electrons to cytochrome $\mathrm{c}^{3}$.

As the concentration of dissolved $\mathrm{H}_{2} \mathrm{~S}$ increased, reduced cytochrome $\mathrm{c}$, reduced cytochrome c oxidase and OCR all decreased reflecting indicating inhibition of step(s) upstream of complex 1 (which appeared irreversible), and subsequently all three parameters increased consistent with donation of electrons directly from $\mathrm{H}_{2} \mathrm{~S}$. In the presence of a mitochondrial fuel entering at complex 2 (succinate), $\mathrm{H}_{2} \mathrm{~S}$ caused a decrease in reduced cytochrome $\mathrm{c}$ and OCR, while increasing reduced cytochrome c oxidase consistent with the simultaneous inhibition of complex 1 and 4 . This analysis highlights the benefit of measuring reductive states of cytochromes concomitantly with OCR: interpreting observed changes in OCR in terms of the mechanisms mediating the changes is not possible with OCR measurements alone. The factors mediating the changes in OCR is distinguished by concomitant measurement of both electron pool sizes in the ETC (cytochromes) and flux of electrons (OCR). Overall, the method was able to characterize complex and multiple effects of $\mathrm{H}_{2} \mathrm{~S}$ on the ETC.

\section{APPENDIX REFERENCES}

1. Rountree, A. et al. BaroFuse, a novel pressure-driven, adjustable-throughput perfusion system for tissue maintenance and assessment. Heliyon 2, e00210 (2016).

2. Khan, A.A. et al. Effects of hydrogen sulfide exposure on lung mitochondrial respiratory chain enzymes in rats. Toxicol Appl Pharmacol 103, 482-490 (1990).

3. Vitvitsky, V. et al. Cytochrome c Reduction by H2S Potentiates Sulfide Signaling. ACS Chem Biol 13, 2300-2307 (2018).

\section{APPENDIX FIGURE LEGENDS}

APPENDIX Fig. 1. Effect of NaHS on ISR by islets. Rat islets (50/channel) were perifused (flow rate $=200 \mathrm{uL} / \mathrm{min}$ ), and ISR was measured in response to glucose and exposure to incrementally increasing concentrations of aqueous NaHS as indicated. Data is average $+/-\mathrm{SE}$, $\mathrm{n}=2$. 
APPENDIX Fig. 2. Effect of $\mathrm{H}_{2} \mathrm{~S}$ on ETC and lactate/pyruvate in rat liver. In the absence $(\mathrm{A}, \mathrm{n}=1))$ or presence of $5 \mathrm{mM}$ succinate $(\mathrm{B}, \mathrm{n}=2)$, liver slices were exposed to increasing levels of $\mathrm{H}_{2} \mathrm{~S}$ until the gas was purged as indicated. OCR, reduced cytochrome $\mathrm{c}$ and cytochrome $\mathrm{c}$ oxidase were measured in real time. Fractions were collected for subsequent measurement of lactate and pyruvate in (A) only. 
bioRxiv preprint doi: https://doi.org/10.1101/2021.03.07.434330; this version posted March 8, 2021. The copyright holder for this preprint (which was not certified by peer review) is the author/funder, who has granted bioRxiv a license to display the preprint in perpetuity. It is made Appendix Fig.
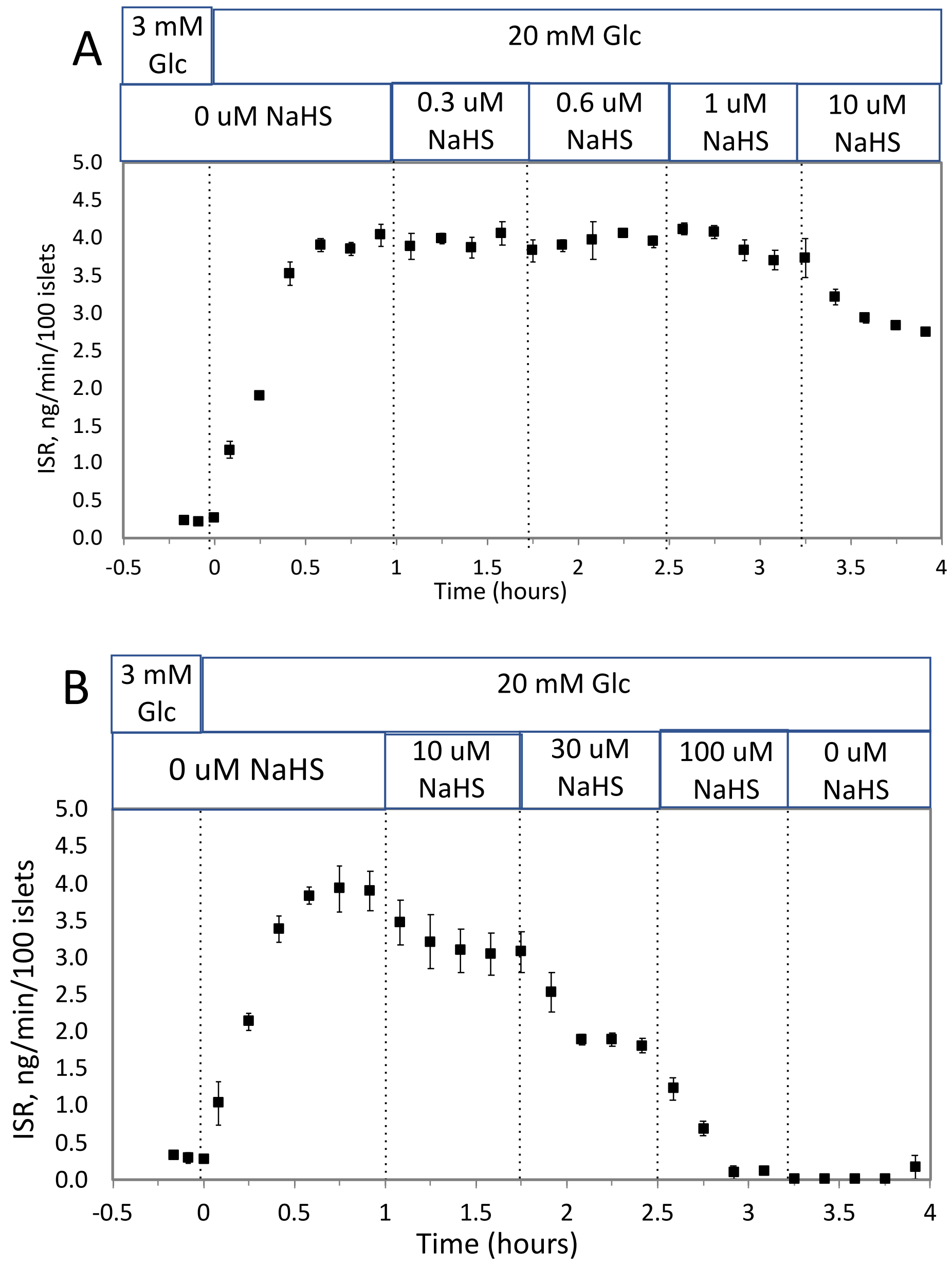
bioRxiv preprint doi: https://doi.org/10.1101/2021.03.07.434330; this version posted March 8, 2021. The copyright holder for this preprint (which was not certified by peer review) is the author/funder, who has granted bioBxiv a license to display the preprint in perpetuity. It is made $\begin{array}{cc}\text { Appendix Fig. } & \sum_{2} \\ 2 \mathrm{~A} & \text { si }\end{array}$
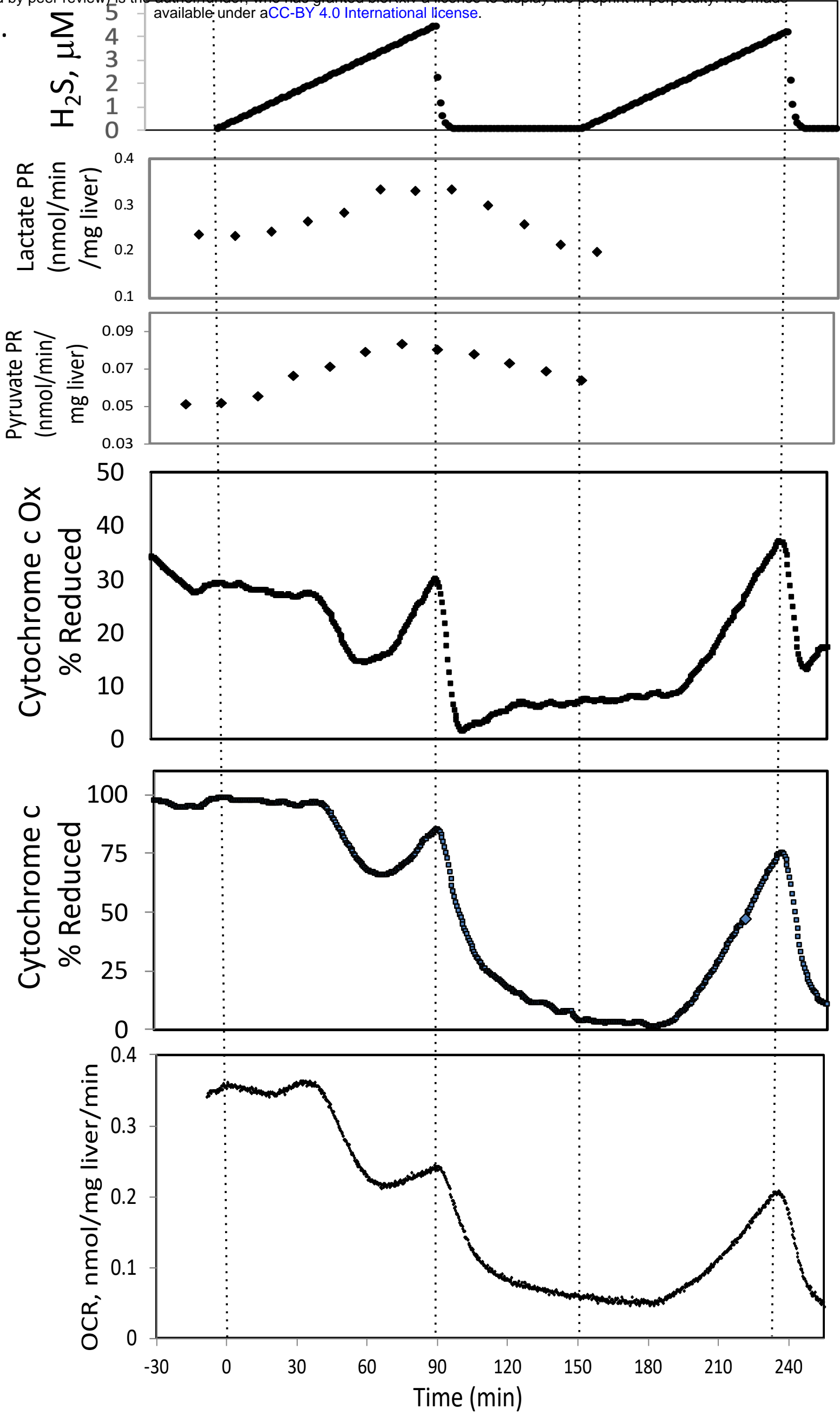
bioRxiv preprint doi: https://doi org/10.1101/2021.03.07.434330; this version posted March 8, 2021. The copyright holder for this preprint (which was not certified by peer review) is the author/funder, who has granted bioRxiv a license to display the preprint in perpetuity. It is made Appendix Fig.

$2 \mathrm{~B}$.
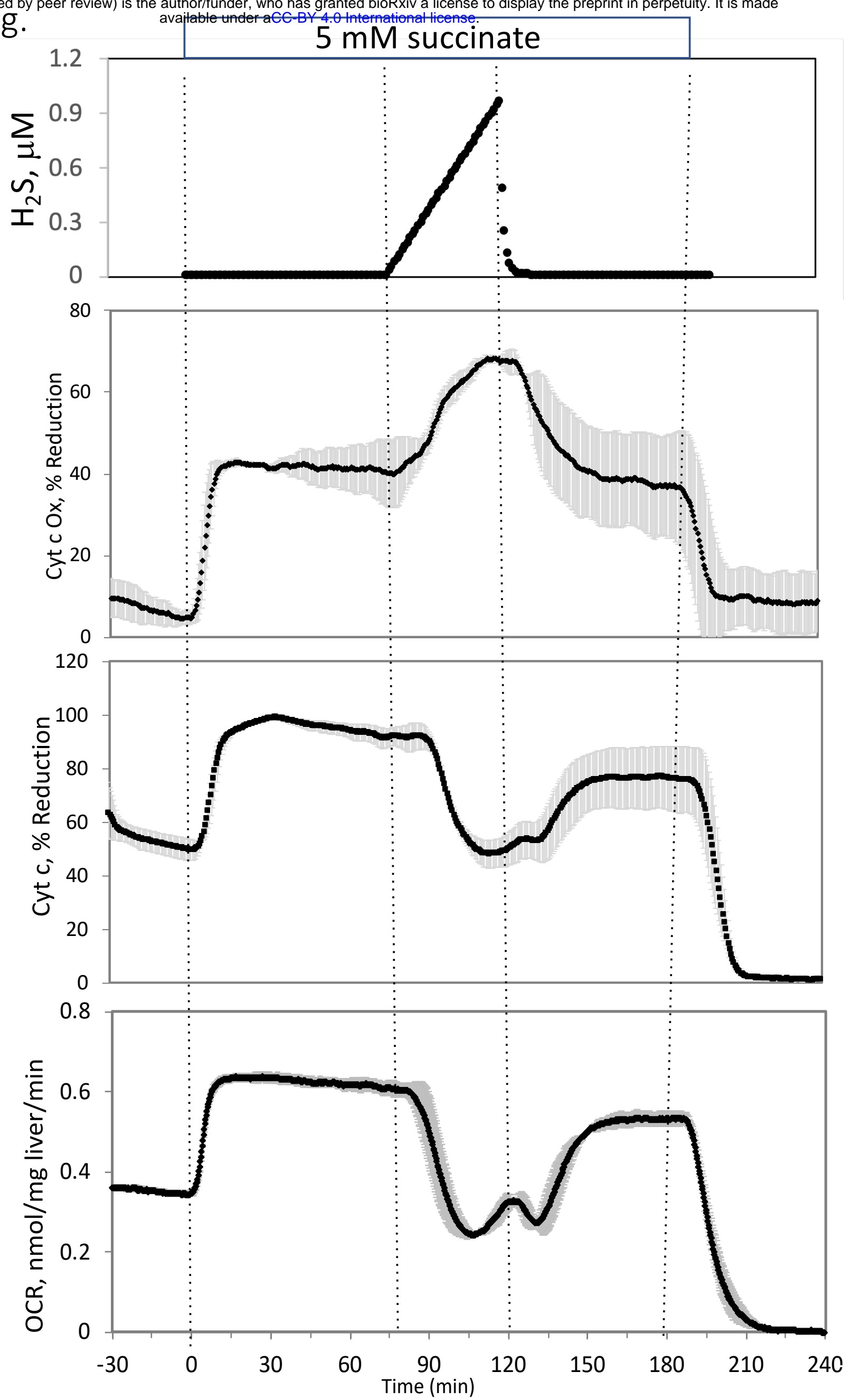